\title{
Transition From Wild to Domesticated Pearl Millet (Pennisetum glaucum) Revealed in Ceramic Temper at Three Middle Holocene Sites in Northern Mali
}

\author{
Dorian Q. Fuller (D) - Aleese Barron - Louis Champion • Christian Dupuy • \\ Dominique Commelin • Michel Raimbault • Tim Denham
}

Accepted: 17 February 2021 / Published online: 16 March 2021

(C) The Author(s) 2021

\begin{abstract}
Imprints of domesticated pearl millet (Pennisetum glaucum (L.) R. Br.) spikelets, observed as temper in ceramics dating to the third millennium $\mathrm{BC}$, provide the earliest evidence for the cultivation and domestication process of this crop in northern Mali. Additional sherds from the same region dating to the fifth and fourth millennium BC were examined and found to have pearl millet chaff with wild morphologies. In addition to studying sherds by stereomicroscopy and subjecting surface casts to scanning electron microscopy (SEM), we also deployed X-ray microcomputed tomography (microCT) on eleven sherds. This significantly augmented the total dataset of archaeological pearl millet chaff remains from which to document the use of the wild pearl millet as ceramic temper and the evolution of
\end{abstract}

D. Q. Fuller

Institute of Archaeology, University College London, 31-34

Gordon Square, London WC1H OPY, UK

D. Q. Fuller

School of Cultural Heritage, Northwest University, Xi'an, China

D. Q. Fuller $(\bowtie)$

Department of Archaeology, Max Planck Institute for the Science of Human History, Jena, Germany

e-mail: d.fuller@ucl.ac.uk

A. Barron · T. Denham

School of Archaeology and Anthropology, Australian National

University, Banks Building, Canberra, ACT 2601, Australia its morphology over time. Grain sizes were also estimated from spikelets preserved in the ceramics. Altogether, we are now able to chart the evolution of domesticated pearl millet in western Africa using three characteristics: the evolution of nonshattering stalked involucres; the appearance of multiple spikelet involucres, usually paired spikelets; and the increase in grain size. By the fourth millennium BC, average grain breadth had increased by $28 \%$, although spikelet features otherwise resemble the wild type. In the third millennium $\mathrm{BC}$, the average width of seeds is $38 \%$ greater than that of wild seeds, while other qualitative features of domestication are indicated by the presence of paired spikelets and the appearance of nondehiscent, stalked involucres. Nonshattering spikelets had probably become fixed by

\section{Champion}

Institute of Archaeological Sciences, Goethe University, Norbert-Wollheim-Platz 1, 60629 Frankfurt am Main, Germany

\section{Champion}

Laboratoire Archéologie et Peuplement de l'Afrique (APA), Anthropology Unit of the Department of Genetics and Evolution (GenEv), University of Geneva, Geneva, Switzerland

\section{Dupuy}

Institut des Mondes Africains (IMAF, UMR 8171, CNRS), Paris, France

D. Commelin · M. Raimbault

Laboratoire Méditerranéen de Préhistoire Europe Afrique (LAMPEA, UMR 7269 CNRS, Aix-en-Provence, France 
around $2000 \mathrm{BC}$, while increases in average grain size continued into the second millennium BC. These data now provide a robust sequence for the morphological evolution of domesticated pearl millet, the first indigenous crop domesticated in western Africa.

Résumé Des empreintes d'épillets de mil domestiqué (Pennisetum glaucum (L.) R. Br.) observées dans des céramiques datées du $3^{\mathrm{e}}$ millénaire av. J.-C. provenant du nord du Mali constituent les plus anciens témoins de la mise en culture et de la domestication de cette céréale. Des tessons supplémentaires issus de la même région se rapportant aux $5^{\mathrm{e}}$ et $4^{\mathrm{e}}$ millénaires av. J.-C. ont été examinés et ont révélé des empreintes de balle de mil de morphologies sauvages. En plus de l'observation de leurs surfaces par stéréo-microscopie, et de l'observation des moulages d'empreintes au microscope à balayage, onze d'entre eux ont fait l'objet des microtomographies aux rayons $\mathrm{X}$ (microCT). Ces examens enrichissent considérablement l'ensemble des données archéologiques concernant l'utilisation du mil sauvage comme dégraissant végétal et son évolution morphologique à travers le temps. La taille des grains a aussi été estimée à partir des épillets conservés dans la céramique. En tenant compte des données enregistrées lors d'études antérieures, nous pouvons désormais retracer l'évolution du mil domestiqué en Afrique de l'Ouest à travers trois caractéristiques : l'évolution des involucres pédonculés à égrenage non-spontané; l'apparition d'involucres multiples par épillets, des épillets appariés le plus souvent; l'augmentation de la taille des grains au vu de leur largeur. Déjà au $4^{\mathrm{e}}$ millénaire avant J.-C., la largeur moyenne des grains a augmenté de $28 \%$ bien que les caractéristiques de l'épillet ressemblent au type sauvage. $\mathrm{Au} 3^{\mathrm{e}}$ millénaire avant J.-C., elle est $38 \%$ supérieure à celle du morphotype sauvage, tandis que des caractéristiques qualitatives de la domestication sont avérées par la présence d'épillets appariés et par celle d'involucres pédonculés à égrenage nonspontané. La non-déhiscence des épillets est un caractéristique de la domesticité qui s'est probablement fixé vers 2000 avant J.-C., tandis que l'augmentation de la taille moyenne des grains s'est poursuivie tout au long $\mathrm{du} 2^{\mathrm{e}}$ millénaire av. J.-C. Ces données fournissent désormais une séquence robuste concernant l'évolution morphologique du mil, la première céréale indigène domestiquée en Afrique de l'Ouest.
Keywords Plant domestication · Neolithic · Later Stone Age $\cdot$ Archaeobotany $\cdot$ MicroCT $\cdot$ Cenchrus americanus

\section{Introduction}

Pearl millet (Pennisetum glaucum (L.) R. Br., [syn. Cenchrus americanus (L.) Morrone]), is one of the most consumed staple crops of sub-Saharan Africa and tropical India (Brunken et al. 1977; Stevens and Fuller 2018). West African agricultural developments began with pearl millet domestication, although the documentation of its domestication process and predomestication exploitation is limited. Once domesticated, pearl millet was integrated within the pastoral subsistence system, providing a potent economic package ready for dispersal. The oldest evidence for this situation is documented in the Lower Tilemsi valley (Mali), where pastoralism and pearl millet cultivation were integrated alongside fishing, hunting, and collecting from $2500 \mathrm{BC}$ (Fig. 1; Manning and Fuller 2014; Manning et al. 2011). A subsequent rapid spread eastward across the Sahara has been postulated based on evidence for domesticated forms reaching eastern Sudan by approximately 1850 BC (Beldados et al. 2018; Winchell et al. 2018) and India, via maritime links, by ca. 1700 BC (Boivin and Fuller 2009; Pokharia et al. 2014).

The wild progenitor of the cultivated pearl millet species has been identified as Pennisetum violaceum (Lam.) Rich. [syn. P. americanum subsp. monodii (Maire) Brunken] (Brunken 1977; Brunken et al. 1977; D'Andrea and Casey 2002). The natural distribution of this species is restricted to the Sahelian zone, from Senegal to northern Sudan (Brunken 1977; Harlan 1992; Upadyaya et al. 2017). However, it is often inferred that domestication occurred in the western part of this range, between Niger and Mauritania (Clotault et al. 2012; Dupuy 2014; Fuller 2003; Fuller and Hildebrand 2013; Tostain 1998). The modeling of modern genomic data fits with the hypothesis of a southwestern Saharan origin for the domesticated form, whence pearl millet spread westward to Mauritania and southward into the savanna south of the Niger River bend (Burgarella et al. 2018).

Here, we report new evidence for wild pearl millet, dating back to the middle Holocene ( $\sim 5000 \mathrm{BC})$, from northeast Mali within the western Saharan zone, and the 
subsequent appearance of domesticated traits by midthird millennium BC. These data derive from the conventional study of impressions on sherd surfaces (see Fuller et al. 2007) and microCT-scanning of sherds' interior content (following the recently developed methods by Barron and Denham 2018; Barron et al. 2017, 2020a, 2020b). We then combine these data with the available long-term archaeological evidence in western Africa to identify the evolutionary trends of pearl millet's domestication and diversification.

\section{Defining and Documenting Domestication in Pearl Millet}

Pearl millet shares many of the same morphological changes known for other cereal domestications (Fuller 2007; Fuller and Allaby 2009; Harlan et al. 1973). In the case of pearl millet, some of these key traits are illustrated in Fig. 2. Some traits, such as the increase in spike length and the increase in grains per harvested head, are not detectable archaeologically. Also difficult to document is the general reduction in the number and length
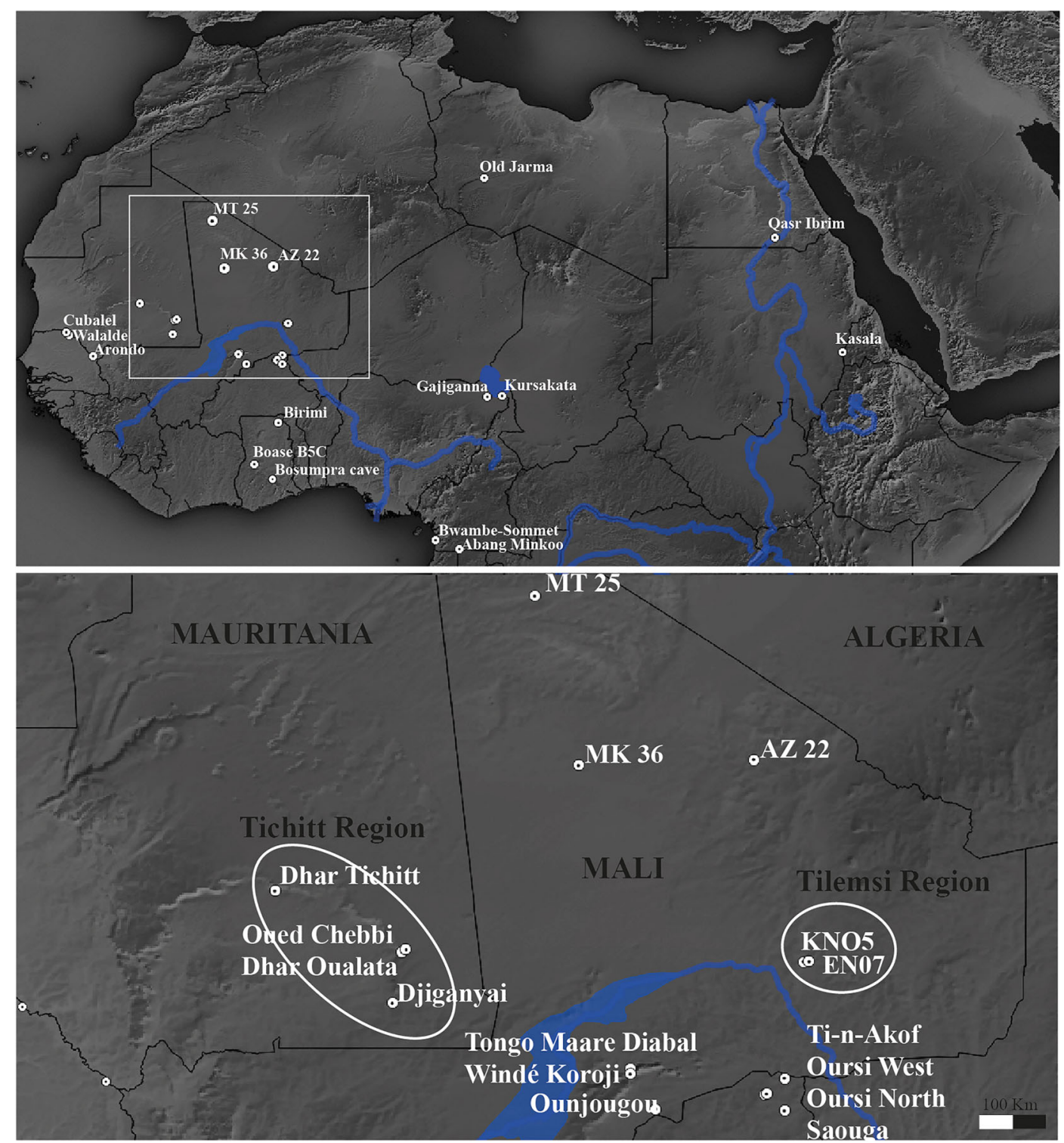

Fig. 1 Map of sites with important archaeological pearl millet evidence, including metrical or morphological domestication evidence. Lower map indicates area of detail, including sites with new evidence reported in this article (MT25, MK36, and AZ22) 
of bristles, which tend to be longer and more prominent in the wild races and more "primitive" in cultivated races. Bristles are reduced, however, alongside increasing grain plumpness in more advanced landraces. Among cultivars, there is a spectrum of variation in how tightly clasped grains are within the husk. The extent to which grains extend beyond the husk is indicative of free-threshing forms. In contrast, the longerclasping chaff, typical of wild Pennisetum violaceum and some of the more bristly ("primitive") cultivars, requires distinct dehusking processes after threshing. Thus, postdomestication evolution includes a reduction in husk length and bristle length, which correlates to pearl millet spikes that are free-threshing and requiring less labor for processing. Although racial subclassifications of pearl millet have been proposed (Brunken et al. 1977), the full spectrum from hulled to free-threshing forms is included in the widespread, basic Pennisetum typhoides race.

Two traits are readily documented archaeologically in cereals. The first, often regarded as the sine qua non of cereal domestication, is the evolution of nonshattering spikes, making seed dispersal reliant on human harvesting, threshing, and sowing. In Pennisetum, wild dispersal is through shattering (abscission) of the involucre, including bristles and spikelet. In domesticated forms, the involucre has developed a nondehiscent stalk (peduncle) below the bristles; the peduncle is torn due to threshing, and this characterizes domestication (see Fig. 2; Brunken et al. 1977; Dupuy 2017; Manning et al. 2011; Poncet et al. 2000). The second trait is an increase in grain size (grain volume), which occurred through increases in breadth and thickness. In pearl millet, grain breadth and
Fig. 2 The morphology of pearl millet, comparing wild (Pennisetum violaceum) and domesticated ( $P$. glaucum) forms. Spike and involucre of $P$. violaceum after Kunth (1835); $P$. glaucum, middle, and stalked involucres after Engler (1895); $P$. glaucum spike, right, after Reale Accademia di Scienze, Lettere ed Arti (1786). Chaff and grain drawings in lower row by DQ Fuller

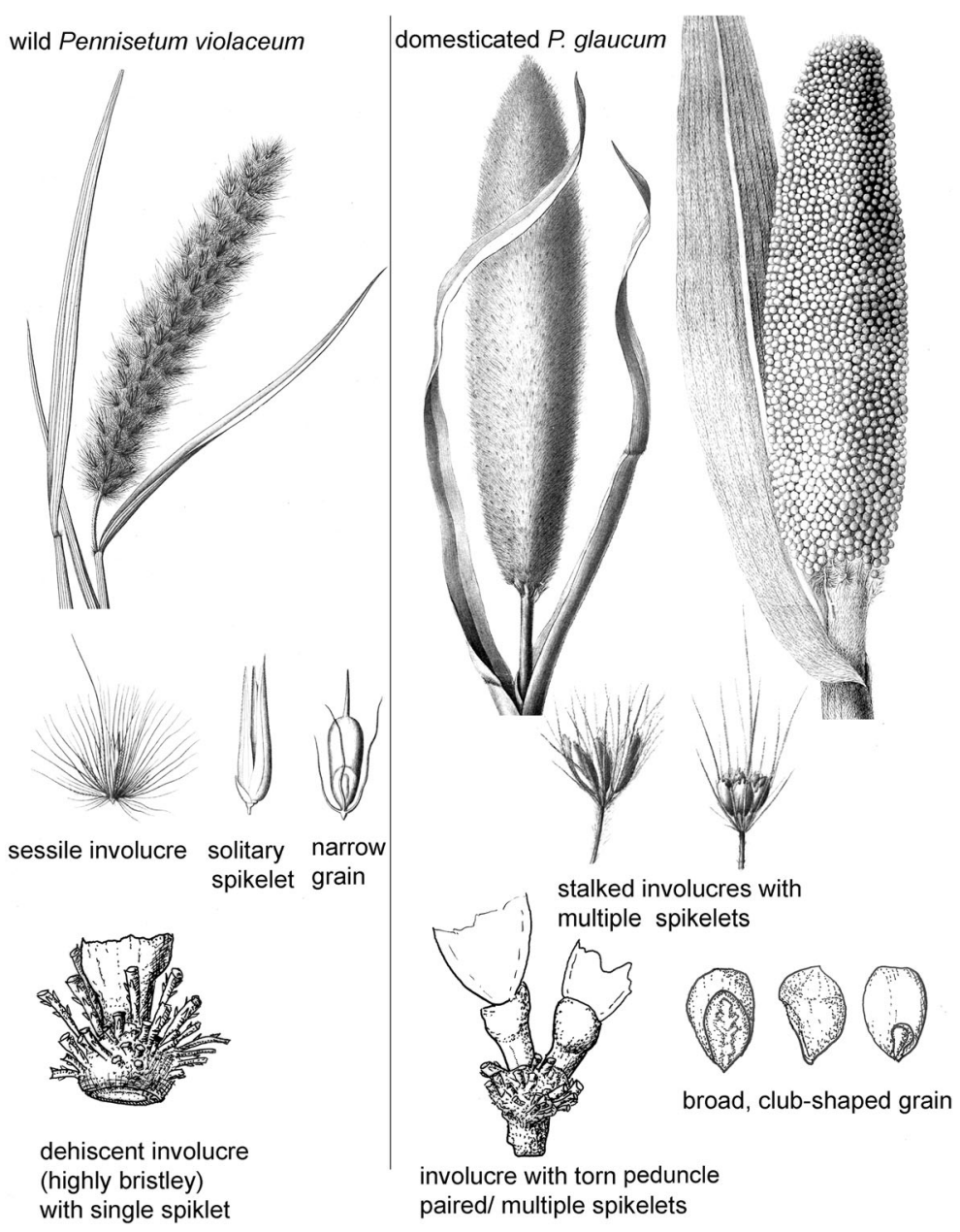


thickness are strongly correlated (usually 1:1), so documenting just one of these dimensions is sufficient for comparing grain size. The enlarged seeds of domesticated pearl millet become markedly obovate or "clubshaped" (D'Andrea et al. 2001; Neumann et al. 1996; Zach and Klee 2003). Grain size increase can be documented through measurements on preserved grains or measurable spikelets in ceramic impressions. Previous studies suggested that a significant increase in Pennisetum grain size was delayed until after primary domestication (in terms of seed dispersal) and that there may have been several regional processes for the selection of grain enlargement (Fuller 2007; Manning et al. 2011). However, this inference may be due, in part, to the lack of evidence for most of the domestication processes that took place before $2500 \mathrm{BC}$. New data reported below allows us to reassess these processes with evidence between $5000 \mathrm{BC}$ and $2000 \mathrm{BC}$. Another change with domestication is the tendency of floret duplication, such that domesticated pearl millet involucres typically have two spikelets, and sometimes three to nine spikelets (Godbole 1928), as opposed to the typically single-grain, single spikelet involucre of wild P. violaceum (Brunken 1977; Fuller et al. 2007). All these three traits of domestication - nonshattering, grain size, and paired spikelets - are examined in this article.

\section{Materials and Methods}

The sites AZ22, MT25, and MK36, were found in 1980 and 1982 by Centre National de la Recherche Scientifique (CNRS) missions, directed by Nicole Petit-Maire (Petit-Maire 1991; Petit-Maire and Riser 1983). During these missions, thousands of sherds were collected from dozens of sites. Currently, those sherds are part of the LAMPEA collection in Aix-en-Provence. Dominique Commelin (1984) and Michel Raimbault (1994) carried out the analysis of this ceramic collection.

The AZ22 site is in Oued Oukechert, near the Erg Ine Sakhane. Hearth charcoals gave a single conventional radiocarbon date of 5500-4950 cal BC (Gif-5228 6340 \pm 130 BP; Commelin et al. 1993). Currently, we cannot confirm that the sherds are contemporaneous with the hearth charcoals. However, due to the presence of lithic artifacts, including scrapers and denticulated blades, we infer a middle Holocene origin for the assemblage (Raimbault 1994, p. 814-816). The MT25 site is located near the Holocene lake, Oum el Assel, in the far northwestern region of Mali, named Erg Chech. This settlement comprises mainly scrapers and notched flakes (Raimbault 1994, p. 338-352). The organic material from a potsherd allowed a direct date of 4240-3090 cal BC (Pa-1023 4890 \pm 230 BP; Commelin et al. 1993). The site MK36 is located south of the two previous sites, more precisely on the southern border of the Erg Jmeya (Raimbault 1994, p. 542-548). Organic vegetal chaff in a spherical pottery fragment (decorated with dotted flames) was radiocarbon dated to 3020-1940 cal BC (Pa-1065 3795 \pm 200 BP; Commelin et al. 1993). As Manning et al. (2011) later noted, a fraction of the organic contents used for the AMS dating may contain old carbon and thus the radiocarbon ages may be some centuries older than the actual age of the ceramic. Nevertheless, MK36 is not older than 3020 BC and is perhaps closer to the middle or the end of the third millennium BC.

These sherds were reexamined for vegetable temper impressions because casts have proven useful for identifying remains of pearl millet elsewhere in West Africa (e.g., Fuller et al. 2007; Klee et al. 2000; Manning et al. 2011), and sorghum domestication in eastern Sudan (Barron et al. 2020b; Winchell et al. 2017, 2018). However, not all vegetable-tempered pottery produces identifiable food plant evidence (Fuller 2013; McClatchie and Fuller 2014). A total of 193 sherds collected from the surface of AZ22, 212 sherds from the surface of MT25, and 1601 sherds from the surface of MK36 were examined under a stereomicroscope at $\times 5-\times 20$ magnifications by Louis Champion. After analysis, twelve sherds from AZ22, two sherds from MT25, and ten sherds from MK36 were selected for further study and were brought to London to cast surface impressions and for scanning electron microscopy (SEM).

Casting and SEM examination began with the sherds from AZ22. Casts of the grain/chaff impressions were made using a vinyl polysiloxane dental molding agent, which was applied to the surface of the potsherds. To have a clean and detailed cast, each sherd was cast three times. These casts were reexamined under the same stereomicroscope, and promising casts were selected for detailed examination by SEM. Recently, a new, nondestructive technique for visualizing the casts of organic temper within sherds, using high-resolution Xray tomography acquired from microCT-scanning, has been pioneered at Australian National University (Barron et al. 2017; Barron and Denham 2018). 
Hence, we decided to explore one sherd from AZ22, using this method to assess the potential increase in data per sherd. The approach can produce a much larger archaeobotanical assemblage from each sherd and provide a more reliable documentation of morphological features in three dimensions (Barron et al. 2020a, 2020b). A study on Sudanese Neolithic sherds tempered with sorghum recovered 12 times more plant remains through microCT than through conventional surface casts. This greatly reduced the proportion of indeterminate remains regarding domesticated or wild status (Barron et al. 2020b). The promise of this approach also led us to examine all ten MK36 sherds using the microCT scanning method.

Sherds were scanned at the National Laboratory for X-ray Micro Computed Tomography (CT Lab) at the Australian National University. The AZ22 sherd was mounted in an aluminum tube (55-mm diameter) and stabilized with packing foam. It was scanned using a Heliscan high-resolution microCT system at $100 \mathrm{kV}$ and a current of $65 \mathrm{~mA}$ for $11 \mathrm{~h}$ with a $3 \mathrm{~mm}$ aluminum filter, resulting in a voxel size of $22 \mu \mathrm{m}$ (Latham et al. 2008; Myers et al. 2011). The MK36 sherds were divided into two groups, based on sherd size, and mounted in aluminum tubes with diameters of $20 \mathrm{~mm}$ and $40 \mathrm{~mm}$, and stabilized with packing foam. These were then scanned using the same Heliscan high-resolution microCT system with a 3-mm aluminum filter at the respective energies of $80 \mathrm{kV}$ and $100 \mathrm{kV}$, currents of $60 \mathrm{~mA}$ and $65 \mathrm{~mA}$, and durations of 10 and $14 \mathrm{~h}$. These resulted in voxel sizes of $7.67 \mu \mathrm{m}$ and $15.59 \mu \mathrm{m}$, respectively. The resultant datasets were rendered using the open-source visualization software Drishti (v. 2.6.5) and Drishti Paint (v. 2.6.5) (Limaye 2012). The distribution of organic inclusions of lower density than the surrounding clay matrix was initially visualized in low resolution (1/64th) before individual inclusions were identified, segmented, and visualized at high resolution (see Barron and Denham 2018).

The maximum breadth of intact spikelets was measured for the impressions and microCT-scan visualizations. Spikelet maximum breadth is a close approximation of maximum grain breadth. As grain thickness and breadth are strongly correlated (Fuller 2007; Zach and Klee 2003), it is sufficient to use breadth to infer grain size differences between populations and change through time. For comparison, data from the literature was gathered to expand our datasets (e.g., Manning et al. 2011). In order to compare impression data with charred grain metrics (which are affected by shrinkage), impression metrics were reduced by $10 \%$ as a correction for the plausible effects of charring (see Fuller 2007). Assemblage means are plotted against a median estimate of site age (following the protocol of Fuller et al. 2012 , 2014). When not available from primary sources, we estimated standard deviations based on sample size, following the factors in Pearson and Hartley (1976).

\section{Results}

AZ22

Out of twelve sherds selected for casting from AZ22, ten produced plant impressions on the surface that were to some degree identifiable (Tables 1 and 2). These included remains that appear to be Panicum sp. $(n=1)$ (Fig. $3 \mathrm{~b}$ ), an unidentified small grass grain $(n=1)$, and, of particular significance, predominant Pennisetum remains, including several bristles and eleven grains in the husk (Fig. 3a), as well as lemma/palea fragments. However, none of these is diagnostic of wild or domesticated status. One sherd, however, preserved a complete Pennisetum involucre, including chaff and bristles and a sessile base (Fig. 3d) indicative of a shattering wild-type panicle (Fig. 3e). This appears to be a singlegrained involucre, which is also typical of wild Pennisetum (Brunken et al. 1977; Marchais 1994), as opposed to the domesticated crop in which the majority ( $\sim 80 \%$ ) of involucres have two or more grains (Fuller et al. 2007; Godbole 1928; Manning and Fuller 2014). Therefore, the overall assemblage of surface impressions suggests exploitation of Pennisetum and the use of processed waste as ceramic temper. However, only a single specimen from the sherd surfaces could be determined as wild or domesticated status.

Results from microCT-scanning and visualization of voids confirm intensive use of pearl millet chaff tempering and the presence of purely shattering wild-type involucres. Many hundreds of spikelets and involucres are present within sherd 27 from AZ22 (Fig. 4). A subsample of 30 complete spikelets was selected for detailed imaging and three-dimensional assessment. The results indicated single grained spikelets within bristles of the involucre; and smooth-based, nonstalked involucres that are morphologically wild (Fig. 5). Combining the microCT and surface cast datasets, we documented 31 wild type involucres and 26 examples of 


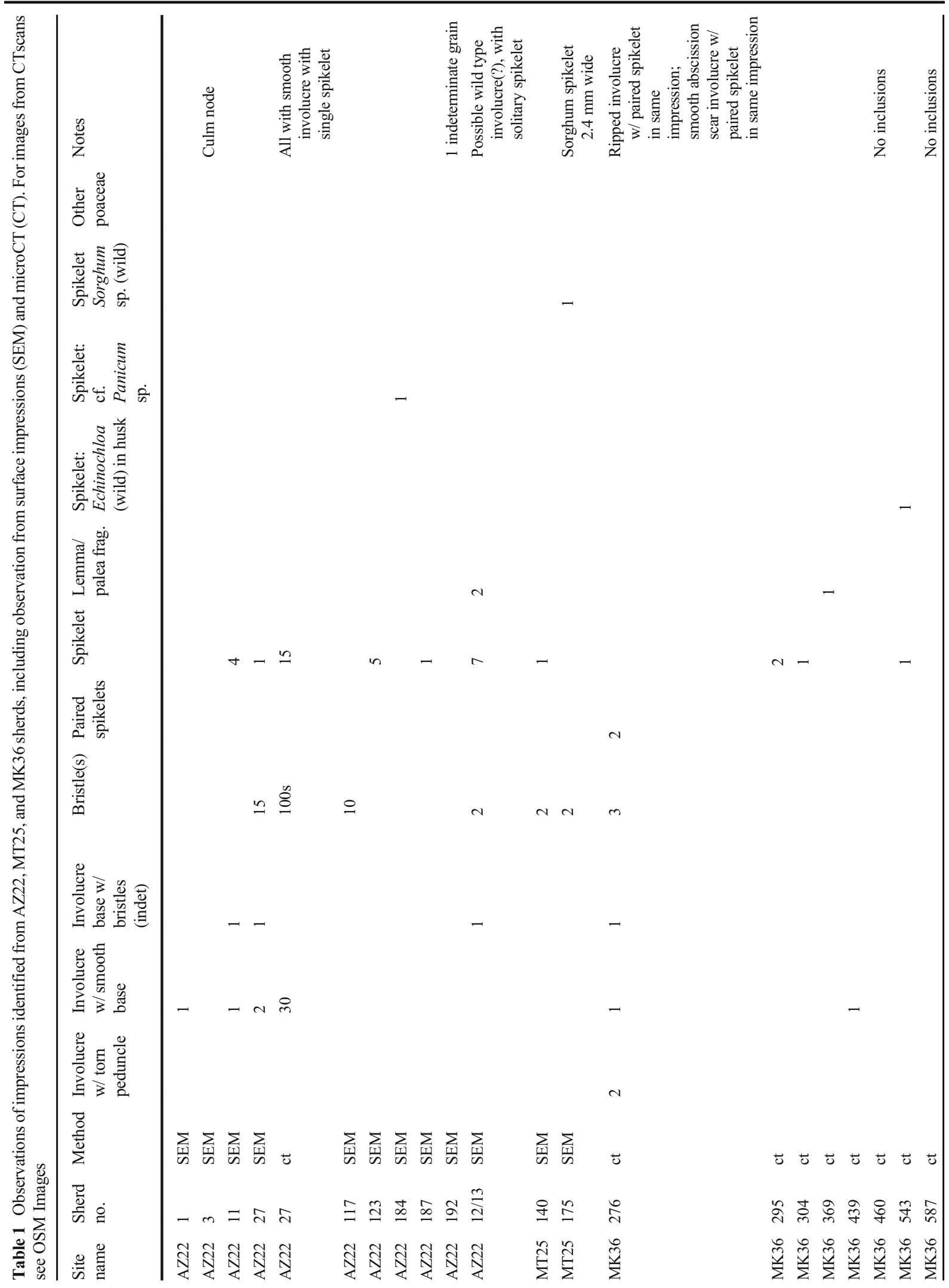




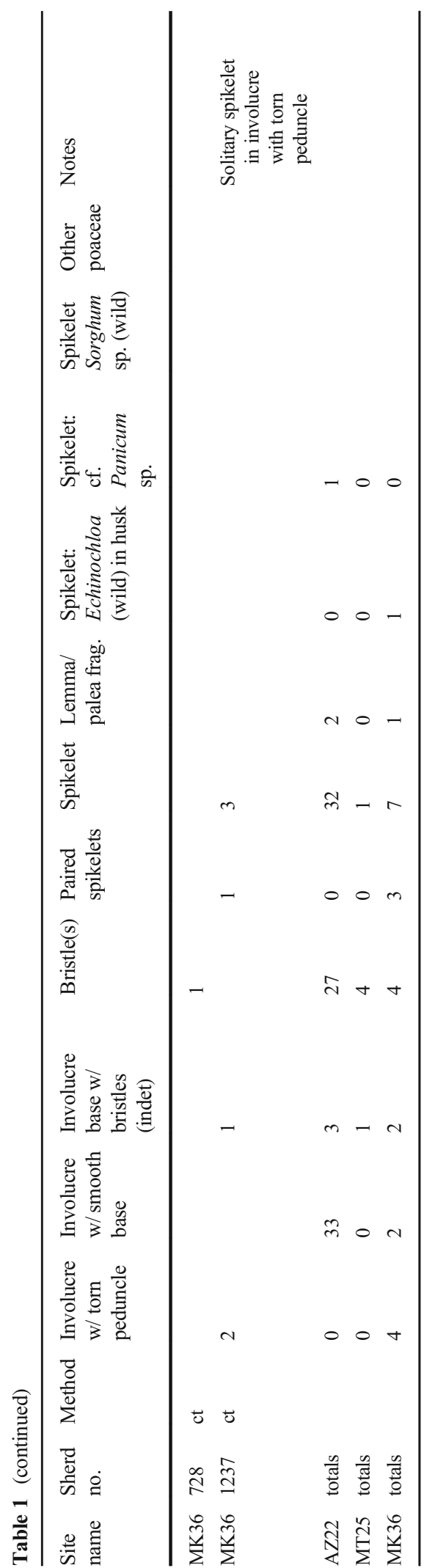

solitary spikelets, but no example of domesticated (stalked) involucre or paired spikelets. The archaeobotanical data are thus consistent with a purely wild pearl millet population.

It should be noted that the grain shape of these impressions is narrow and lacks the thickened, clubshaped morphology that is typical of domesticated grains (see D'Andrea et al. 2001; Manning and Fuller 2014; Zach and Klee 2003). Twenty-eight measurements, representing maximum grain breadth, were obtained from spikelet impressions and the microCT visualizations to study grain sizes. Grain breadths ranged from $0.69 \mathrm{~mm}$ to $1.08 \mathrm{~mm}$, with an average of $0.89 \mathrm{~mm}$, which falls in the range expected of wild millet, i.e., 0.5$1 \mathrm{~mm}$ (Fuller 2007; Zach and Klee 2003), and the average is $0.80 \mathrm{~mm}$ when reduced by $10 \%$ (to make them comparable to charred material).

MT25

Only a few sherds from the assemblage at MT25 exhibited obvious chaff-tempering. Of these, two sherds were cast for surface impressions (Tables 1 and 2). These showed obvious Pennisetum bristles, a single involucre apex with bristle bases and a solitary spikelet, and five additional spikelets, but there are no involucre base remains that demonstrate domestication status. Breadth measurements on these spikelets ranged from $0.7 \mathrm{~mm}$ to $1.2 \mathrm{~mm}$ (average of $0.97 \mathrm{~mm}$ ). While the average falls within the range of modern wild $P$. violaceum, the upper part of the range $(>1 \mathrm{~mm}$ ) suggests a deviation from the expected wild range. The mean is $0.87 \mathrm{~mm}$ when reduced by $10 \%$, which is comparable to the reported average of early domesticated carbonized grains ( $\sim 0.9$ mm) (D'Andrea et al. 2001; Zach and Klee 2003).

\section{MK36}

From MK36, ten sherds were chosen based on the promising surface impressions. These were studied through microCT scanning (Tables 1 and 2). Out of seven involucres within the resultant visualized assemblage, four had torn peduncles of the domesticated type, while two showed stalkless, dehiscent types (Fig. 5). In three cases, paired spikelets were indicated, while one had a solitary spikelet. Seven additional spikelets were indeterminate as to pairing. Therefore, at a minimum of $27 \%$ ( 3 out of 11), spikelets came from pairs. Breadth could be measured on nine visualized spikelets, giving a 


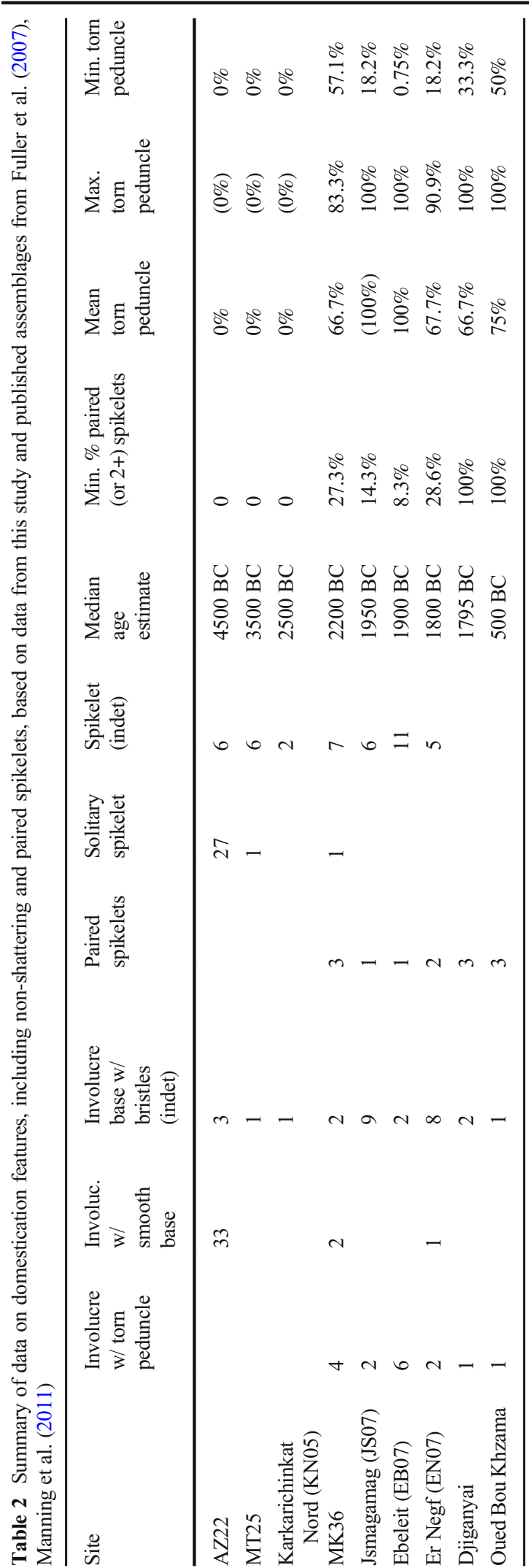

0.93-1.53 $\mathrm{mm}$ range (average $1.14 \mathrm{~mm}$ ), and the mean is $1.03 \mathrm{~mm}$ when reduced by $10 \%$, indicating that these grains fall clearly within the domesticated size range. The pearl millet data from these three sites are summarized in Table 2 alongside similar data published from Mali and Mauritania.

\section{Discussion and Further Analysis}

In the fifth millennium BC in northern Mali, represented by AZ22, the overall plant assemblage suggests that Pennisetum dominated other small grasses that were incorporated into some sherds. The AZ22 assemblage provided a point in time and space when the collection of wild Pennisetum was an important part of the food economy, and its processing produced abundant chaff that was utilized as ceramic temper. The AZ22 data is part of a small but growing evidence of wild Pennisetum utilization in Africa. The evidence has also been reported from southwest Libyan sites of the late Acacus period (6500-5000 BC), including Ti-n-Torha, Uan Muhuggiag, and UanTabu, where charred seeds of wild Pennisetum were recovered (Mercuri 2001; Wasylikowa 1993), and Takrakori where desiccated Pennisetum grains and chaff were found (Mercuri et al. 2018). However, these cases plausibly represent the desert grass, $P$. divisum, rather than the crop progenitor $P$. violaceum. Taken together, though, these finds point to traditions of wild Pennisetum harvesting across the central and western Sahara during the Early to Middle Holocene, which could constitute the cultural background for the later cultivation of Pennisetum violaceum and its subsequent domestication (Dupuy 2014; Manning and Fuller 2014). In the case of the Acacus region of Libya, however, Pennisetum sp. drops out of use by ca. $6200 \mathrm{BC}$, with subsequent plant exploitation and probable cultivation focusing on small millets, such as Panicum and Echinochloa (Mercuri et al. 2018). Indeed, Winchell et al. (2018) suggest three distinct, yet parallel, pathways to cereal cultivation in Africa that were each initially based on different grasses: small millet cultivation in the central Sahara, sorghum in the eastern Sahel, and pearl millet in the western Sahel.

Wild pearl millet was plausibly a grain staple millennia before the earliest evidence of its domestication in the later third millennium BC. From this time onward, morphological changes that are characteristic of the domestication process are documented at many 
sites, including MT25 and MK36. These data support the initiation of pearl millet cultivation and domestication in the western Sahara desert/Sahel region, in what is today northern Mali. This archaeobotanical interpretation is consistent with a recent genomic study about the location of pearl millet's initial domestication (Burgarella et al. 2018). It appears that the initial exploitation of pearl millet took place north of its modern wild range (Fig. 6). This northerly location accorded with the expected northward displacement of grasslands during the African Humid Period, which ended around 5000 years ago (De Menocal 2015; Manning and Timpson 2014). As the Sahara expanded and the Sahelian vegetation zone retreated south, pearl millet

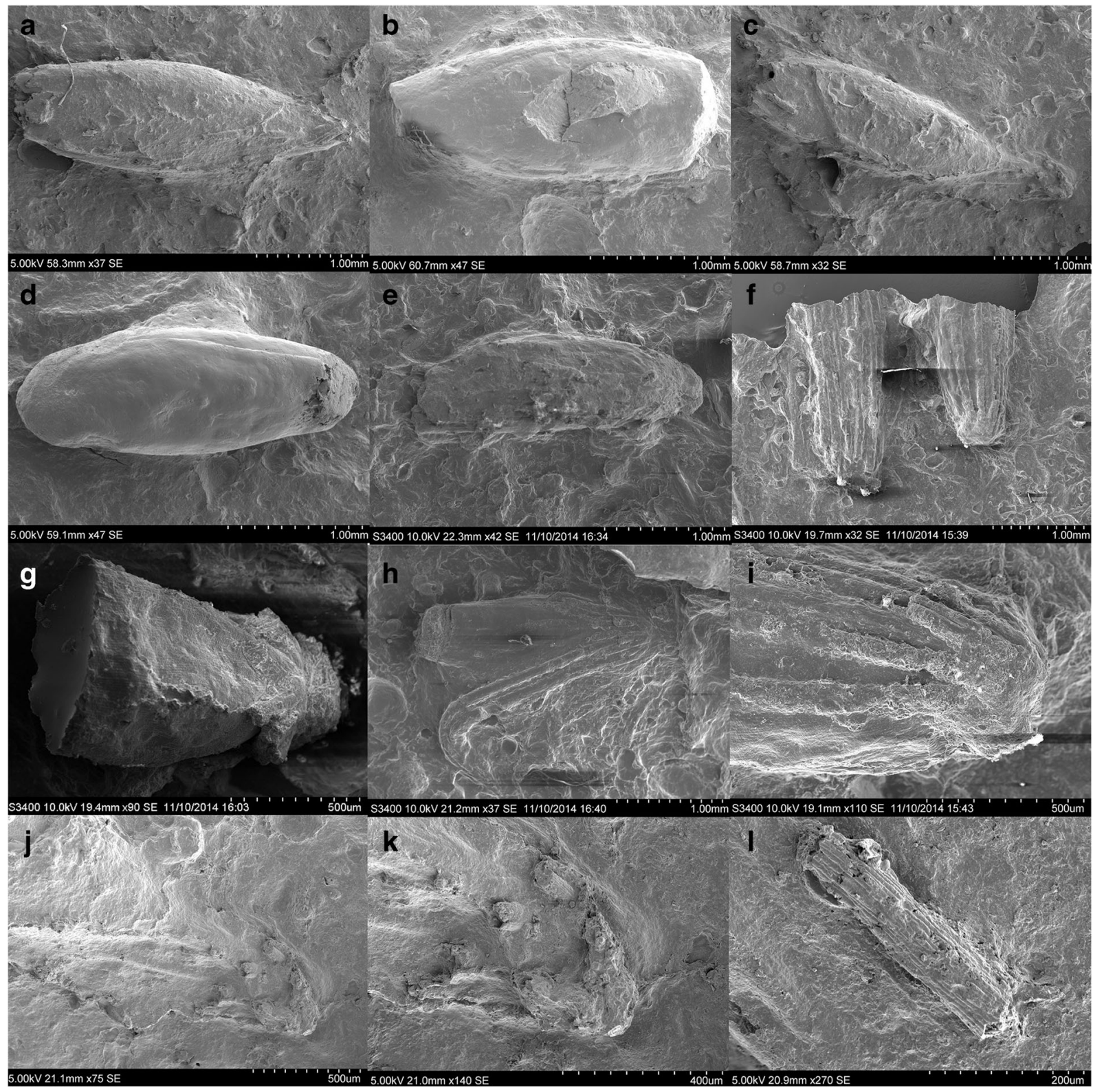

Fig. 3 Example of surface chaff impressions from AZ22 studied by SEM: a-e single-grained spikelets (a-c AZ sherd 11; d-e AZ22 sherd 123); f involucres with bristle bases, indeterminate type left, and sessile right (AZ22 sherd 11); g solitary spikelet and bristles of involucre on indeterminate type (AZ22 sherd 27); $\mathbf{h}-\mathbf{i}$ solitary spikelet in sessile involucre (AZ22 sherd 1); $\mathbf{j}-\mathbf{k}$ solitary spikelet and bristles of involucre on indeterminate type (AZ22 sherd 12/13); I bristle fragment (AZ22 sherd 12/13) 
would have already been under early predomestication cultivation.

The fourth millennium BC dataset from site MT25 is consistent with a morphologically wild population, although it is a very small sample. Grain breadth here was larger on average than recorded at AZ22, marked by an increase in the mean grain breadth of $\sim 28 \%$. The latest data from MK36 indicates that the pearl millet that was being exploited in far northern Mali during the later third millennium $\mathrm{BC}$ was undergoing domestication. This site lies north of both the modern wild distribution (Fig. 6) and around the northern limits of traditional cultivation (Bindinger et al. 1982; Wotzka 2019), suggesting that domestication of pearl millet initially took place in the southwestern part of the "Green Sahara," prior to final aridification during the middle Holocene (De Menocal 2015). Nonshattering forms were present, which exhibited stalked involucres that are expected to exist and be selected only in contexts of routine cultivation and human harvesting. However, the cooccurrence of these domesticated morphotypes with wild morphotypes could indicate that these populations were in the middle of the domestication episode. In addition, paired spikelets indicate selection for this trait, which increases yield per spike. In wild populations, multigrain involucres are expected to be rare as they will make diaspores less aerodynamic and less easily dispersed and buried, whereas human harvesting removed any deleterious consequences for the plant. Also, grain breadth had increased in terms of average size and maximum breadth by comparison to the earlier data from AZ22 and MT25. The average grain breadth at MK36 was $\sim 38 \%$, larger than AZ22.

The archaeobotanical evidence from MK36 suggests an ongoing domestication process. The insights from the better-studied regions like southwest Asia indicate that the MK36 materials were in the "Entrenched PreDomestication Cultivation" phase. During this period, domestication traits like nonshattering occur at a rate of $20-80 \%$ in the cereal population, and grain sizes increase on average by $20-40 \%$ (Fuller et al. 2018). Based on such southwest Asian comparisons, we can hypothesize that cultivation had likely begun approximately 1000-1500 years earlier, by $\sim 4000$ BC, possibly overlapping with or just postdating the AZ22 evidence.

In order to assess the wider domestication process of pearl millet, we can consider these new data alongside previously published evidence. This includes previous work on ceramic impressions that provide some information on chaff features, including nonshattering
Fig. 4 MicroCT visualizations for AZ22, sherd 27: a wholesherd exterior surface; $\mathbf{b}$ all organic inclusion casts. Lower row presents dorsal (c) and ventral views (d) of a sessile (wild-type) involucre cast (Inclusion 1) containing a single spikelet. For more examples, see Supplementary Images.

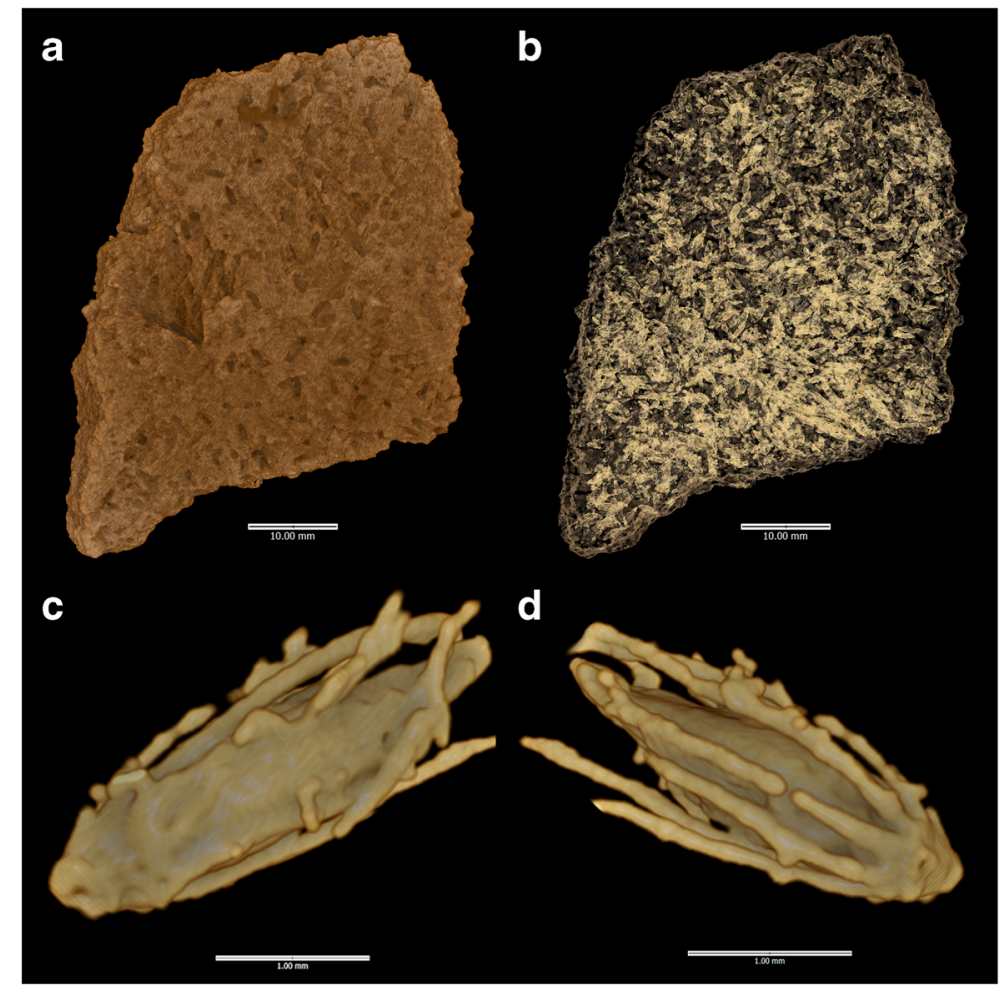


involucres and paired/multiple spikelets (Table 2). Prior work includes evidence from the Lower Tilemsi Valley, where eight out of the nine diagnostic impressions were of the domesticated type around the end of the third millennium BC (Manning et al. 2011). In addition, evidence from Mauritania (1900-1500 BC), although not documented quantitatively, indicates the predominance of stalked, nonshattering involucres and doublegrained involucres (Amblard and Pernès 1989; Fuller et al. 2007; MacDonald et al. 2009).

The limited quantitative data for shattering/ nonshattering involucres have been used to plot estimates of the minimum and maximum nonshattering proportions (taking into account indeterminate remains), using median age estimates for each site (Fig. 7: top). In addition, the proportion of paired as opposed to solitary spikelets has also been estimated, which similarly indicates divergence from solitary spikelets before the end of the third millennium BC and a dominance of paired spikelets from the first half of the second millennium BC (Fig. 7: bottom). Although the data are limited, the trends from both eastern Mauritania and the Lower
Tilemsi Valley in Mali indicate the end of the domestication process, in terms of selection for nonshattering, took place between the third and second millennium $\mathrm{BC}$. Both regions seem to have received, from earlier cultural traditions such as those represented by MK36 and MT25, cultivated pearl millet that was undergoing domestication.

In order to further track the domestication and postdomestication evolutionary processes in pearl millet, we reviewed the evidence for grain size change (Fig. $8)$. We have compiled published measurements and, when not available, have made new estimates from published images with scales (Table 3). By recording means, standard deviations, and assemblage extremes (maximum and minimum) and plotting these against median ages for a site or site phase, long term trends are evident. Impressions and desiccated grains were reduced by $10 \%$ to make measurements more comparable to charred grains (Fuller 2007). Spikelet maximum breadth, taken from surface impressions, is regarded as equal to the breadth of grains. While such data can be expected to incorporate some noise due to the vagaries
Fig. 5 MicroCT visualizations for MK36, sherd 1237: a stalked involucre with bristles (nonshattering, domesticated type) (Inclusion 1); b spikelet (Inclusion 3); c spikelet in involucre, seen in lateral view, suggesting paired spikelet form torn involucre stalk $\left(\mathbf{c}^{\prime}=\right.$ ventral view of the same) (Inclusion 11); d single spikelet (Inclusion 12); e two rotated views of spikelet in involucre, suggesting solitary spikelet and sessile (wild type) involucre (Inclusion 13). For the complete dataset, see

Supplementary Images

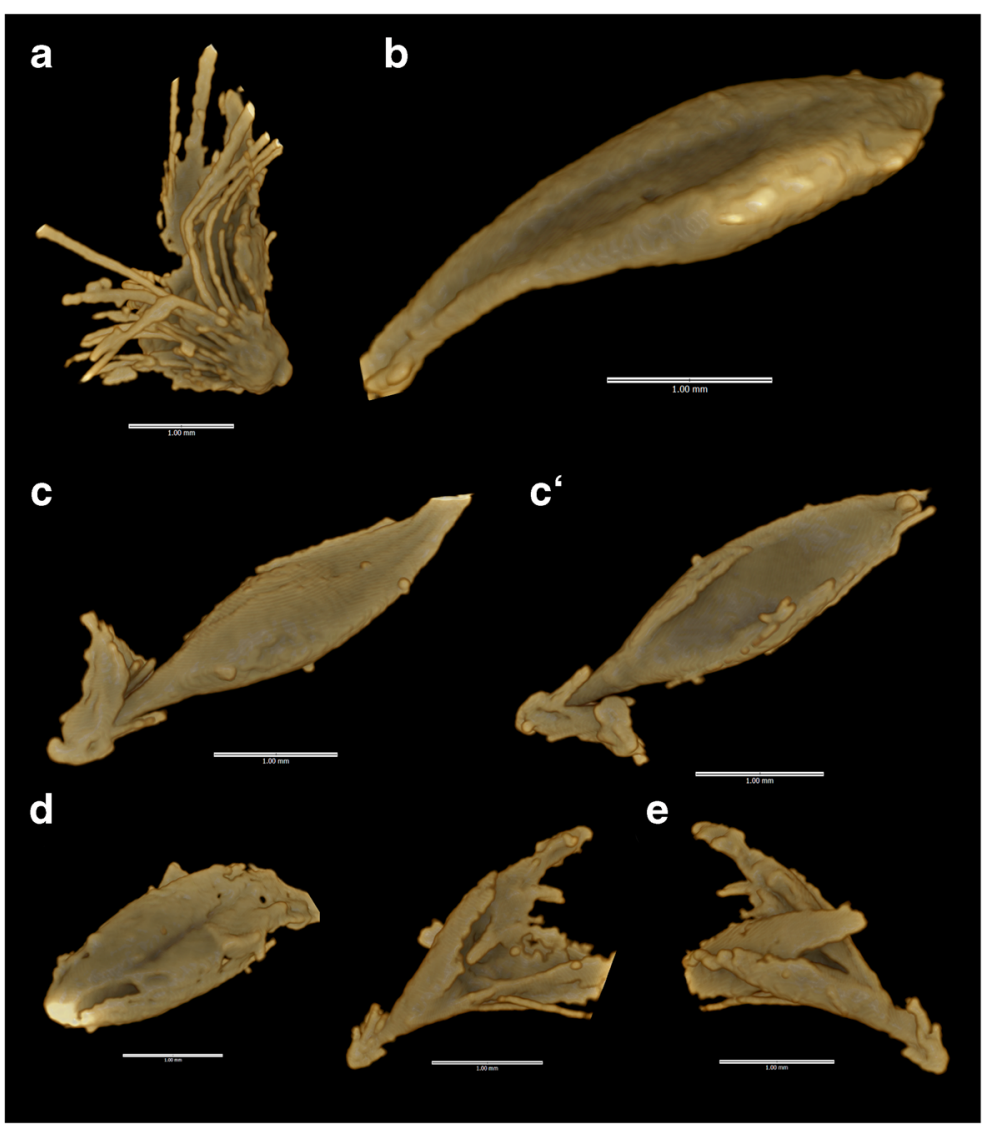


of carbonization, we can still expect to record long-term trends in average size and range (Bonhomme et al. 2016; Fuller et al. 2014, 2017). Our total African dataset of pearl millet grain metrics comprises 2736 measurements, dating from ca. $4500 \mathrm{BC}$ to $1500 \mathrm{AD}$, including assemblages from 27 sites across mainly the western African region (Fig. 1). Although the sample size for many assemblages is small, these data nevertheless allow some assessment of long-term chronological trends in pearl millet grain size and determine how this trait evolved in relation to domestication and postdomestication evolution (Fig. 8).

Three major patterns can be discerned in the pearl millet grain size data (Fig. 8). First, there is a clear trend for the average grain breadth to increase in size from the beginning of the time series: from $0.8 \mathrm{~mm}$ before 4000 $\mathrm{BC}$ to between $1.3 \mathrm{~mm}$ and $1.7 \mathrm{~mm}$ after $\mathrm{AD} 750$. The overall trend in increasing size is statistically significant. The trend was tested with a Mann-Kendall Trend test, which tests for directional (monotonic) trends in time series data (Mann 1945), performed in Past 3.1 software (Hammer et al. 2001). The test shows that the trend is significantly directional ( $p=0.0026798$ for a nondirectional, random trend). Second, the overall variation in size around the mean increases over time, a phenomenon also noted in grain size data for wheat and barley (Fuller et al. 2017). Third, the upper range-maximum breadth measurements - tends toward larger sizes, whereas the minimum sizes remain about the same (note polynomial trend lines in Fig. 8). Taking the upper limits of grain size, one can contrast the maximum size of $\sim 1.5 \mathrm{~mm}$ at ca. $2200 \mathrm{BC}$ with $\sim 2.1 \mathrm{~mm}$ at ca. $1660 \mathrm{BC}$ and increasing to $2.5 \mathrm{~mm}$ by $1100 \mathrm{BC}$.

Considering the earlier part of this time series in more detail, we can suggest two phases in the trend for size increase: (1) an early phase of the Later Stone Age trend (4500-2200 BC), that we associate with the initial domestication process, in which there were size increases of $\sim 0.01 \%$ per year; and (2) a terminal phase of the Later Stone Age size trend (2500-1150 BC), in which the rate of increase became $\sim 0.04 \%$ per year. These two phases of size change can be translated into estimates of Haldane rate, which measures the shift in the distribution of a phenotypic trait per generation (see Purugganan and Fuller 2011) from $\sim 6.4 \times 10^{-3}$ haldanes (earlier) to $11.4 \times 10^{-3}$ (later). These rates of size increase are comparable to the rates of change estimated for several other grain domesticates (Fuller et al. 2014). Subsequent to this, there were no directional trends in

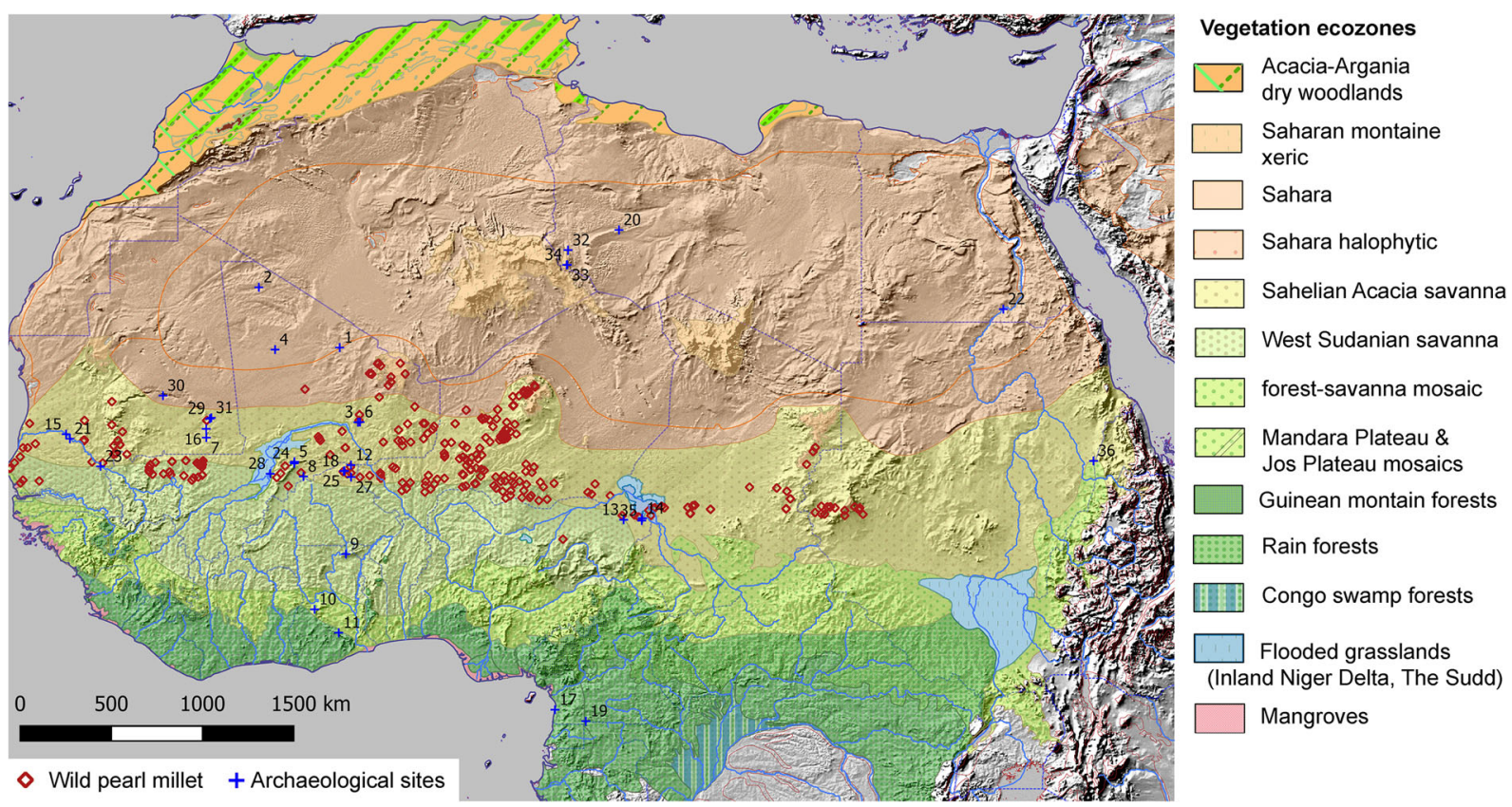

Fig. 6 Map of distribution of modern wild pearl millet in relation to modern vegetation zones (after Olson et al. 2001), also showing locations of archaeological sites with early Pennisetum discussed in this article (numbers correspond to those in Table 3). For sources of ecozone boundaries and wild pearl millet, see "Acknowledgements". The coordinates of modern wild pearl millet populations are in Supplementary Table S1; and archaeological sites with wild pearl millet are in Supplementary Table S2. 
the average, but rather an interassemblage variation with means in breadth fluctuating between $\sim 1.1 \mathrm{~mm}$ and $\sim 1.7$ $\mathrm{mm}$. Similar interassemblage variations have been observed in wheat and barley grain sizes in Europe and West Asia, which show a directional increase during the Pre-Pottery Neolithic (9000-6000 BC) and subsequently much more variation in the mean and maximum size (6000-3000 BC) during postdomestication (Fuller et al. 2017).

The interassemblage variation in pearl millet after ca. $1500 \mathrm{BC}$ shows evidence of postdomestication diversification. Recent work on domestication genetics has highlighted distinct evolutionary phases of domestication and diversification (Meyer and Purugganan 2013), with the latter including genetic changes and adaptations particular to some regional populations of the crop. Significant evolution usually occurred as crops were translocated and adapted to a diverse geographical and cultural distribution (Fuller and Lucas 2017; Gepts 2014). The four cultivated races, with differing geographies, are characterized by differences in grain shape (Brunken et al. 1977), indicating that postdomestication evolution indeed involved grain size variation. None of these varieties became as small and thin as wild forms, although long, thin grains characterize race Leonis in western coastal Africa (e.g., Sierra Leone). As pearl millet spread from the Sahelian range of its wild progenitor (95\% of wild populations occur from $12.4^{\circ}-19^{\circ}$ $\mathrm{N})$, it encountered much higher rainfall levels and differing seasonality. Its dispersal into the equatorial wet tropics brought about selection for loss of day-length sensitivity. This necessitated the development of earlyflowering varieties that could be sown and harvested before the peak of rainfall in late summer instead of lateflowering varieties that share with the wild form flowering tied to shortening days at the end of summer (Clotault et al. 2012; Dussert et al. 2015). While modern genomic studies have revealed many other loci that underwent selection as regional varieties differentiated, such as spike length (related to yield), root system size (related to drought tolerance), and bristle length (related in resistance to some insects), it remains the case that "the genetic basis of environmental adaptation in pearl millet has not been well understood" (Serba et al. 2020).

There are likely trends toward larger grains of pearl millet varieties that spread south into the wetter tropics and desert oases. In the dataset reviewed here, sites south of Latitude $10^{\circ} \mathrm{N}$ have above-average grain breadths (>1.29 mm, e.g., Abang Minko, BwambeSommet, Bosumpra, Boase B5C). The same is for sites in desert latitudes such as Old Jarma and Qasr Ibrim, which might reflect varieties adapted to cultivation with

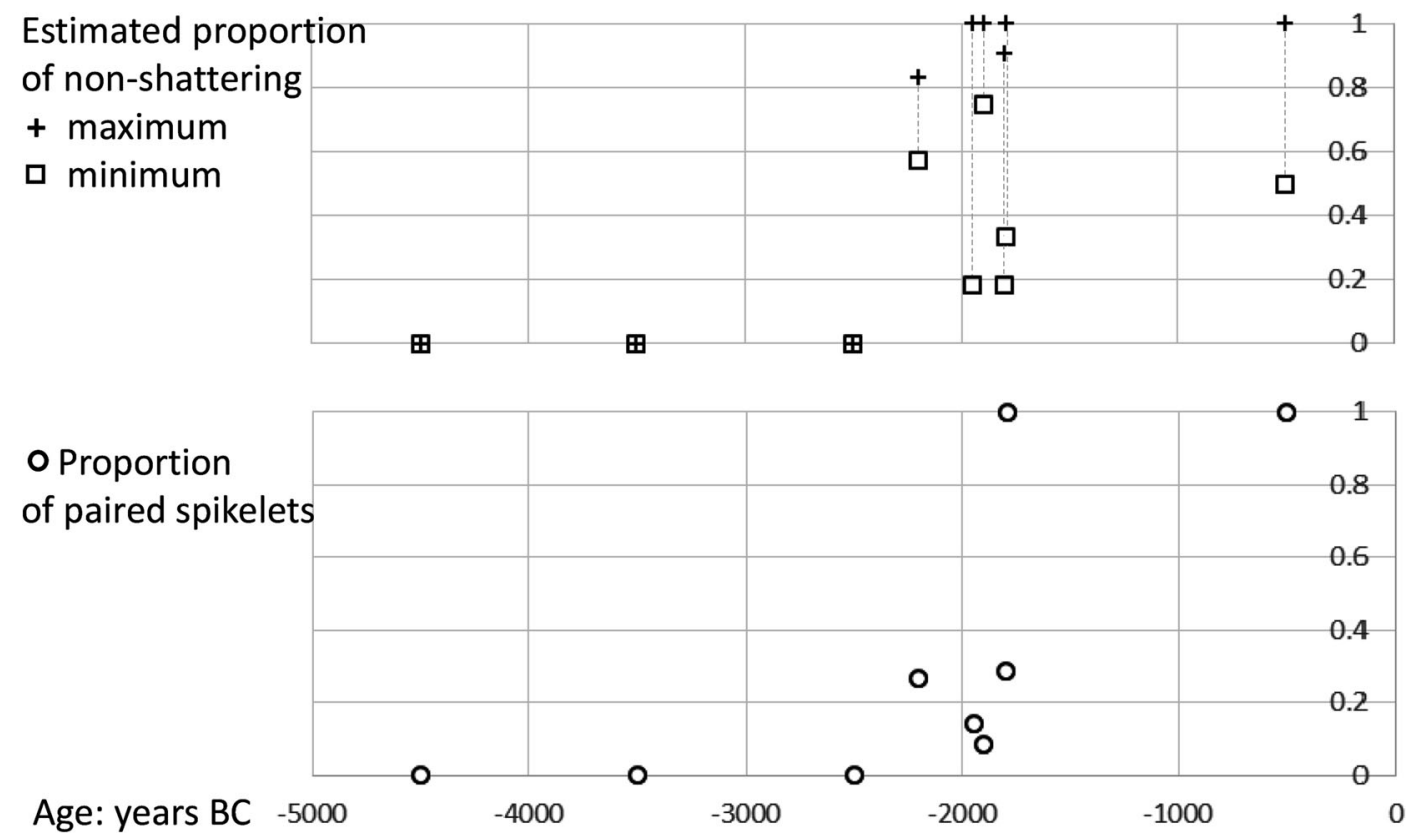

Fig. 7 Trends in domestication traits based on early impression data, plotted against median calendrical age. Upper graph indicates maximum and minimum estimates of the proportion of non- shattering (stalked involucres). Lower graph indicates observed proportion of paired spikelets. Data: Table 2 
irrigation. Previously identified variation in Indian archaeological pearl millet (Fuller 2007; Manning et al. 2011), between smaller grains in semiarid western India versus much plumper grains in the better-watered Ganges plains, could suggest a similar pattern. These cases support the hypothesis that pearl millet varieties grown under and adapted to wetter conditions had more plump grains, on average. It is unknown at this stage how much of this is underpinned by genetic changes as opposed to phenotypic plasticity, which is also increasingly discussed as a potential factor in some changes under cultivation (Denham et al. 2020; Larson et al. 2014; Piperno 2017). The data compiled in this study provide an initial and partial understanding of the trends of grain size change connected to domestication due to the wide dispersal and diversification of pearl millet. They call for systematic recording of grain size across many more sites.

\section{Conclusions}

The research on pearl millet impressions and inclusions in ceramics highlights the great potential of studying ceramic assemblages in regions like Northern Mali for chaff-tempering remains. Such data may provide crucial evidence on past plant use and regional pathways to agriculture. This study also highlights how much additional data becomes available by using new microCT scanning methods to look inside sherds (as per Barron et al. 2020a; Barron et al. 2020b). This offers much greater whole-sherd, quantitative potential for archaeobotanical studies than the traditional study of impressions by surface casting. By reanalyzing ceramic collections from northern Mali, using new methods, we have generated new data on pearl millet domestication.

Our evidence indicates that wild pearl millet was being exploited in northern Mali in the fifth millennium $\mathrm{BC}$ and that predomestication cultivation was probably established sometime in the fourth millennium BC. The appearance of morphological domestication traits is clearly established by the middle of the third millennium BC. The domesticated pearl millet was introduced to adjacent regions, including the Hodh depression of Mauritania and the Lower Tilemsi Valley in Mali toward the end of the third millennium BC; and southern Mali, northern Ghana, and the Lake Chad region by the first half of the second millennium BC. These data provide an improved understanding of how pearl millet evolved domestication traits, including nonshattering

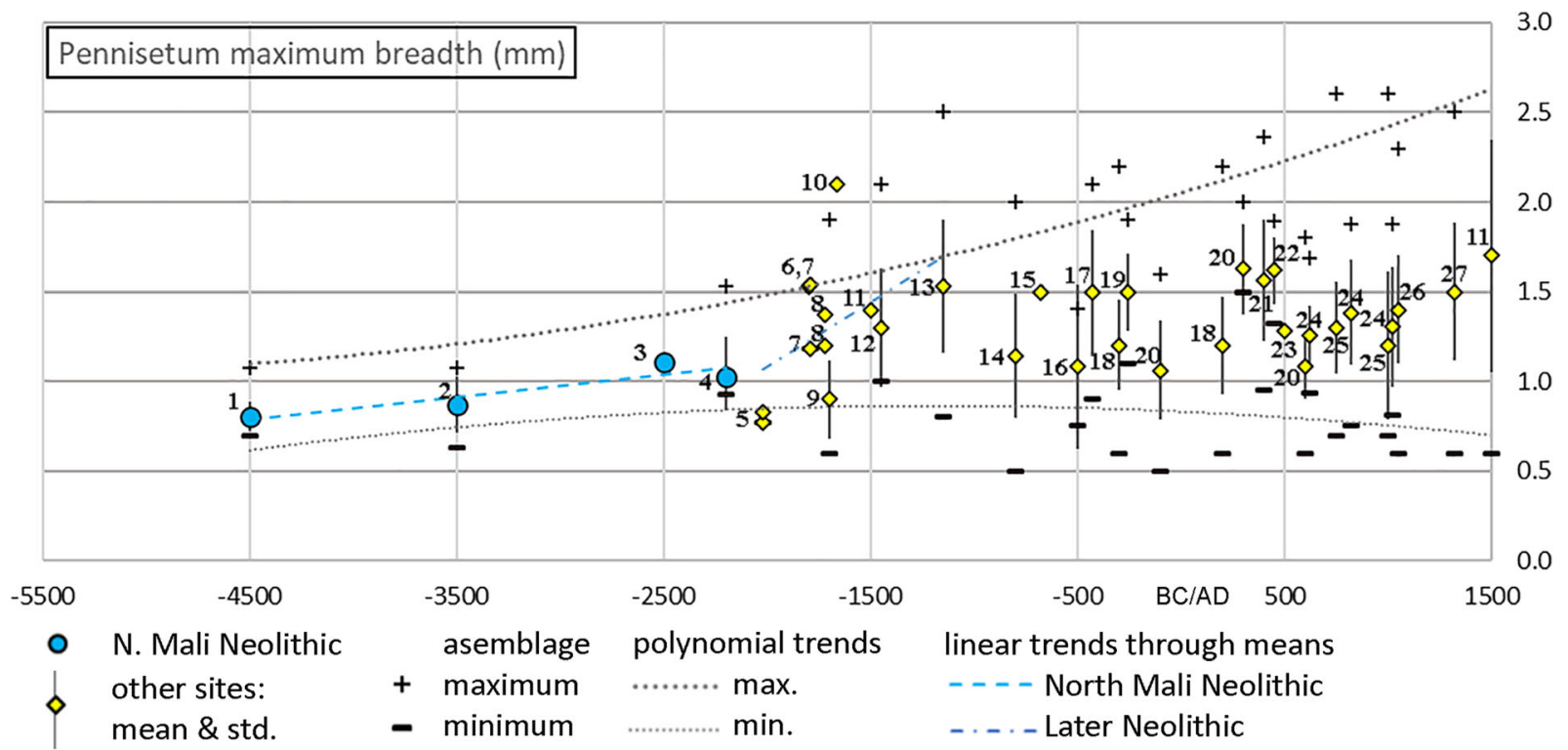

Fig. 8 Grain size change in archaeological pearl millet: polynomial trends lines through the maximum and minimum archaeological grain sizes have been determined by default settings in Microsoft Excel. Linear regression lines illustrate two phases of evolutionary trends in average grain size increase, during domestication (based on AZ22, MT25, MK36 and KN05) and subsequent secondary enlargement (based on MK36, Er Negf, Ounjougou, Brimi, Bosumpra Cave, Ti-n-Akof and Ganjiganna). Impression measurements and desiccated grains (Qasr Ibrim) have been reduced by $10 \%$ to make them more comparable to charred material. Sites numbered as per Table 3 
Table 3 Summary of grain size (maximum breadth) data from archaeological pearl millet across western and Saharan Africa. Desiccated grins (Qasr Ibrim) and estimates from pottery impression spikelets corrected by $-10 \%$ to improve comparability to charred grains. In some cases measurements have been estimated from photographs in the original source

\begin{tabular}{|c|c|c|c|c|c|c|c|c|}
\hline No & Site & $\begin{array}{l}\text { Median age }(-\mathrm{BC} / \\
\mathrm{AD})\end{array}$ & $\begin{array}{l}\text { Breadth } \\
\text { Ave }\end{array}$ & Stdev & Min & Max & $n$ & Source \\
\hline 1 & AZ22 & -4500 & 0.803 & 0.082 & 0.692 & 1.077 & 28 & This study \\
\hline 2 & MT25 & -3500 & 0.870 & 0.158 & 0.630 & 1.080 & 6 & This study \\
\hline 3 & $\begin{array}{l}\text { Karkarichinkat Nord } \\
\text { (KNO5) }\end{array}$ & -2500 & 1.110 & & & 1.110 & 1 & Manning and Fuller (2014) \\
\hline 4 & MK36 & -2200 & 1.046 & 0.208 & 0.931 & 1.526 & 9 & This study \\
\hline 5 & Winde Koroji & -2025 & 0.770 & & 0.770 & & 1 & MacDonald et al. (2017) \\
\hline 5 & Winde Koroji & -2025 & 0.825 & & & 0.825 & 1 & MacDonald et al. (2017) \\
\hline 6 & Er Negf (EN07) & -1800 & 1.530 & & & 1.530 & 1 & Manning and Fuller (2014) \\
\hline 7 & Djiganyai & -1795 & 1.54 & & & 1.540 & 1 & Fuller et al. (2007) \\
\hline 7 & Djiganyai & -1795 & 1.181 & & 1.181 & & 1 & Fuller et al. (2007) \\
\hline 8 & Ounjougou & -1725 & 1.371 & & & 1.371 & 1 & Ozainne et al. (2009) \\
\hline 8 & Ounjougou & -1725 & 1.200 & & & & 1 & Ozainne et al. (2009) \\
\hline 9 & Birimi & -1700 & 0.900 & 0.220 & 0.600 & 1.900 & 376 & D'Andrea et al. (2001) \\
\hline 10 & Boase: B5C & -1665 & 2.100 & & & 2.100 & 1 & D'Andrea et al. (2006) \\
\hline 11 & Bosumpra cave & -1500 & 1.400 & & & & 1 & Oas et al. (2015) \\
\hline 12 & Ti-n-Akof & -1450 & 1.300 & 0.330 & 1.000 & 2.100 & 18 & Kahlheber (2004) \\
\hline 13 & Gajiganna & -1150 & 1.530 & 0.374 & 0.800 & 2.500 & 30 & Kahlheber (2004) \\
\hline 14 & Kursakata (weighted ave) & -800 & 1.142 & 0.346 & 0.500 & 2.000 & 41 & Zach and Klee (2003) \\
\hline 15 & Walalde & -675 & 1.500 & & & & 1 & Murray and Déme (2014) \\
\hline 16 & Oued Bou Khzama & -500 & 1.081 & 0.457 & 0.758 & 1.404 & 3 & After Fuller et al. (2007) \\
\hline 17 & Bwambe-Sommet & -425 & 1.500 & 0.346 & 0.900 & 2.100 & 15 & Kahlheber et al. (2009) \\
\hline 18 & Oursi West & -300 & 1.200 & 0.252 & 0.600 & 2.200 & 800 & Kahlheber (2004) \\
\hline 19 & Abang Minkoo & -260 & 1.500 & 0.214 & 1.100 & 1.900 & 18 & Kahlheber et al. (2009) \\
\hline 20 & Old Jarma & -100 & 1.062 & 0.278 & 0.500 & 1.600 & 21 & Pelling (2007); Fuller et al. (2007) \\
\hline 18 & Oursi West & 200 & 1.200 & 0.270 & 0.600 & 2.200 & 400 & Kahlheber (2004) \\
\hline 20 & Old Jarma & 300 & 1.625 & 0.250 & 1.500 & 2.000 & 4 & Pelling (2007); Fuller et al. (2007) \\
\hline 21 & Cubalel & 400 & 1.562 & 0.340 & 0.951 & 2.360 & 35 & $\begin{array}{l}\text { New metrics; cf. Murray et al. } \\
\text { (2007) }\end{array}$ \\
\hline 22 & Qasr Ibrim & 450 & 1.620 & 0.185 & 1.320 & 1.890 & 10 & Steele and Bunting (1982) \\
\hline 23 & Arondo & 500 & 1.280 & & & & 1 & Zach and Klee (2003) \\
\hline 20 & Old Jarma & 600 & 1.082 & 0.176 & 0.600 & 1.800 & 254 & Pelling (2007); Fuller et al. (2007) \\
\hline 24 & Tongo Maare Diabal (1-2) & 625 & 1.256 & 0.166 & 0.938 & 1.688 & 41 & Champion (2019) \\
\hline 25 & Oursi North & 750 & 1.300 & 0.256 & 0.700 & 2.600 & 60 & Kahlheber (2004) \\
\hline 24 & Tongo Maare Diabal (3) & 825 & 1.383 & 0.292 & 0.750 & 1.875 & 25 & Champion (2019) \\
\hline 25 & Oursi North & 1000 & 1.200 & 0.410 & 0.700 & 2.600 & 262 & Kahlheber (2004) \\
\hline 24 & Tongo Maare Diabal (4-5) & 1025 & 1.304 & 0.333 & 0.813 & 1.875 & 30 & Champion (2019) \\
\hline 26 & Saouga & 1050 & 1.400 & 0.300 & 0.600 & 2.300 & 90 & Kahlheber (2004) \\
\hline 27 & Toguere Doupwil & 1325 & 1.500 & 0.385 & 0.600 & 2.500 & 143 & Bedaux et al. (1978) \\
\hline 11 & Bosumpra Cave & 1500 & 1.700 & 0.646 & 0.600 & 4.000 & 5 & Oas et al. (2015) \\
\hline
\end{tabular}


spikes, paired/multiple spikelets, and larger grain sizes. Grain metrics indicate a general trend of increasing grain breadth during predomestication cultivation (4500$2500 \mathrm{BC}$ ), with acceleration in average size increase from the mid-third millennium $\mathrm{BC}$ to the second millennium BC. This trend toward increasing average grain size and the upper limits of size range is, therefore, a reasonable proxy for inferring the domestication process. However, the increasing variability in grain size and other modalities of diversification through time was also affected by the dispersal of the crop to different ecologies. We have also been able to update and improve estimates for the evolutionary rate of grain size increase in pearl millet, making it the best-documented indigenous plant domestication process in Africa.

Supplementary Information The online version contains supplementary material available at https://doi.org/10.1007/s10437021-09428-8.

Acknowledgements We thank the anonymous peer reviewers for their positive and constructive comments. Archaeobotanical laboratory work has been supported by the "Comparative Pathways to Agriculture" (ComPAg) project, funded by European Research Council advanced grant awarded to Dorian Q. Fuller (ERC Grant \#323842), including travel for Louis Champion to Aix-en-Provence. The reexamination of the Malian sherds was developed within the framework of the interdisciplinary program AfriCrop (ANR-13-BSV7-0017) managed by Yves Vigouroux (IRD Montpellier). MicroCT-scanning research at ANU was supported by the Australian Government Research Training Program (RTP) Scholarship to Aleese Barron, and an Australian Research Council Future Fellowship (FT150100420), and a CASS Small Research Grant to Tim Denham. The authors would like to thank the National Laboratory for X-ray Micro Computed Tomography (ANU CT Lab), particularly Levi Beeching and Michael Turner, for access to and use of CT scanning facilities. We are also graeful to Tim Senden, Research School of Physics and Engineering (ANU), for his continued guidance and support. The distribution map of Pennisetum violaceum in Fig. 6 is based on germplasm accession data accessed through GENESYS Global Portal on Plant Genetic Resources, http://www.genesys-pgr.org, on 8 April 2020. The ecozones in Fig. 6 were downloaded from World Wildlife Fund (https://www. worldwildlife.org/publications/terrestrial-ecoregions-of-theworld), and similar local zones were then grouped.

\section{Declarations}

Conflict of interest The authors declare no conflict of interest or ethical concerns with this paper.
Open Access This article is licensed under a Creative Commons Attribution 4.0 International License, which permits use, sharing, adaptation, distribution and reproduction in any medium or format, as long as you give appropriate credit to the original author(s) and the source, provide a link to the Creative Commons licence, and indicate if changes were made. The images or other third party material in this article are included in the article's Creative Commons licence, unless indicated otherwise in a credit line to the material. If material is not included in the article's Creative Commons licence and your intended use is not permitted by statutory regulation or exceeds the permitted use, you will need to obtain permission directly from the copyright holder. To view a copy of this licence, visit http://creativecommons.org/licenses/by/4.0/.

\section{References}

Amblard, S., \& Pernès, J. (1989). The identification of cultivated pearl millet (Pennisetum) amongst plant impressions on pottery from Oued Chebbi (Dhar Oualata, Mauritania). African Archaeological Review, 7(1), 117-126. https://doi. org/10.1007/BF01116840.

Barron, A., \& Denham, T. P. (2018). A microCT protocol for the visualisation and identification of domesticated plant remains within pottery sherds. Journal of Archaeological Science: Reports, 21, 350-358. https://doi.org/10.1016/j. jasrep.2018.07.024.

Barron, A., Turner, M., Beeching, L., Bellwood, P., Piper, P., Grono, E., Jones, R., Oxenham, M., Kien, N. K. T., Senden, T., \& Denham, T. P. (2017). MicroCT reveals domesticated rice (Oryza sativa) within pottery sherds from early Neolithic sites (4150-3265 cal BP) in Southeast Asia. Scientific Reports, 7(1), 7410. https://doi.org/10.1038 /s41598-017-04338-9.

Barron, A., Datan, I., Bellwood, P., Wood, R., Fuller, D. Q., \& Denham, T. (2020a). Sherds as archaeobotanical assemblages: Gua Sireh reconsidered. Antiquity, 94(377), 13251336.

Barron, A., Fuller, D. Q., Stevens, C., Champion, L., Winchell, F., \& Denham, T. (2020b). Snapshots in time: MicroCT scanning of pottery sherds determines early domestication of sorghum (Sorghum bicolor) in East Africa. Journal of Archaeological Science, 123, 105259.

Bedaux, R. M. A., Constandse-Westermann, T. S., \& Hacquebord, L. (1978). Recherches archéologiques dans le Delta intérieur du Niger (Mali). Palaeohistorica, 20, 91-220.

Beldados, A., Manzo, A., Murphy, C., Stevens, C. J., \& Fuller, D. Q. (2018). Evidence of Sorghum cultivation and possible pearl millet in the second millennium BC at Kassala, Eastern Sudan. In A. M. Mercuri, A. C. D'Andrea, R. Fornaciari, \& A. Höhn (Eds.), Plants and people in the African past (pp. 503-528). Cham: Springer.

Bindinger, F. R., Mahalakshmi, V., Talukdar, B. S., \& Alagarswamy, G. (1982). Improvement of drought resistance in pearl millet. In International Rice Research Institute (Ed.), Drought resistance in crops with emphasis on rice (pp. 357375). Manila: International Rice Research Institute. 
Boivin, N., \& Fuller, D. Q. (2009). Shell middens, ships and seeds: Exploring coastal subsistence, maritime trade and the dispersal of domesticates in and around the ancient Arabian Peninsula. Journal of World Prehistory, 22(2), 113-180.

Bonhomme, V., Forster, E., Wallace, M., Stillman, E., Charles, M., \& Jones, G. (2016). The first shoots of a modern morphometrics approach to the origins of agriculture. Web Ecology, 16(1), 1-2. https://doi.org/10.5194/we-16-1-2016.

Brunken, J. N. (1977). A systematic study of Pennisetum sect. Pennisetum (Gramineae). American Journal of Botany, 64(2), 161-176.

Brunken, B., Jere, N., de Wet, J. M. J., \& Harlan, J. R. (1977). The morphology and domestication of pearl millet. Economic Botany, 31, 163-174.

Burgarella, C., Cubry, P., Kane, N. A., Varshney, R. K., Mariac, C., Liu, X., Shi, C., Thudi, M., Couderc, M., Xu, X., Chitikineni, A., Scarcelli, N., Barnaud, A., Rhoné, B., Dupuy, C., François, O., Berthouly-Salazar, C., \& Vigouroux, Y. (2018). A Western Sahara centre of domestication inferred from pearl millet genomes. Nature Ecology \& Evolution, 2, 1377-1380. https://doi.org/10.1038/s41559018-0643-y.

Champion, L. (2019). The evolution of agriculture, food and drink in the ancient Niger River Basin: Archaeobotanical studies from Mali and Benin. Ph.D. dissertation. University College London.

Clotault, J., Thuillet, A. C., Buiron, M., De Mita, S., Couderc, M., Haussmann, B. I., Mariac, C., \& Vigouroux, Y. (2012). Evolutionary history of pearl millet (Pennisetum glaucum [L.] R. Br.) and selection on flowering genes since its domestication. Molecular Biology and Evolution, 29(4), 11991212.

Commelin, D. (1984). Céramique néolithique du Sahara malien. In Thèse de Doctorat 3ème Cycle. Aix-Marseille II: Université.

Commelin, D., Raimbault, M., \& Saliège, J.-F. (1993). Nouvelles données sur la chronologie du Néolithique au Sahara malien. Comptes rendus de l'Académie des sciences, 317(2), 543550.

D'Andrea, A. C., \& Casey, J. (2002). Pearl millet and Kintampo subsistence. African Archaeological Review, 19(3), 147-173.

D'Andrea, A. C., Klee, M., \& Casey, J. (2001). Archaeobotanical evidence for pearl millet (Pennisetum glaucum) in subSaharan West Africa. Antiquity, 75(288), 341-348.

D'Andrea, A. C., Logan, A. L., \& Watson, D. J. (2006). Oil palm and prehistoric subsistence in tropical West Africa. Journal of African Archaeology, 4(2), 195-222.

De Menocal, P. B. (2015). Palaeoclimate: End of the African humid period. Nature Geoscience, 8(2), 86-87.

Denham, T. P., Barton, H., Castillo, C., Crowther, A., DotteSarout, E., Florin, A., Pritchard, J., Barron, A., Zhang, Y., \& Fuller, D. Q. (2020). The domestication syndrome in vegetatively propagated field crops. Annals of Botany, 125 , 581-597.

Dupuy, C. (2014). Des céréales et du lait au Sahara et au Sahel de l'Épipaléolithique à l'âge des métaux. Revue Afriques, débats, méthodes et terrains d'histoire, 5, 1376.

Dupuy, C. (2017). La domestication du mil et ses implications sociétales. Le Saharien, 220, 16-39.

Dussert, Y., Snirc, A., \& Robert, T. (2015). Inference of domestication history and differentiation between early-and late- flowering varieties in pearl millet. Molecular Ecology, 24(7), $1387-1402$.

Engler, A. (1895). Die Pflanzenwelt Ost-Afrikas und der Nachbargebiete. Band 3. Berlin: D. Reimer.

Fuller, D. Q. (2003). African crops in prehistoric South Asia-A critical review. In K. Neumann, A. Butler, \& S. Kahlheber (Eds.), Food, fuel and fields: Progress in African archaeobotany (pp. 239-271). Köln: Heinrich-Barth-Institut (Africa praehistorica 15).

Fuller, D. Q. (2007). Contrasting patterns in crop domestication and domestication rates: Recent archaeobotanical insights from the Old World. Annals of Botany, 100(5), 903-924.

Fuller, D. Q. (2013). Observations on the use of botanical materials in ceramic tempering at Gobero. In E. A. A. Garcea (Ed.), Gobero: The No-Return frontier. Archaeology and landscape at the Saharo-Sahelian borderland (pp. 241248). Journal of African Archaeology Monograph Series 9. Frankfurt am Main: Africa Magna.

Fuller, D. Q., \& Allaby, R. G. (2009). Seed dispersal and crop domestication: Shattering, germination and seasonality in evolution under cultivation. In L. Østergaard (Ed.), Fruit development and seed dispersal (pp. 238-295). Oxford: Wiley-Blackwell (Annual Plant Reviews 38).

Fuller, D. Q., \& Hildebrand, E. A. (2013). Domesticating plants in Africa. In P. J. Mitchell \& P. J. Lane (Eds.), The Oxford handbook of African archaeology (pp. 507-525). Oxford: Oxford University Press.

Fuller, D. Q., \& Lucas, L. (2017). Adapting crops, landscapes, and food choices: Patterns in the dispersal of domesticated plants across Eurasia. In M. Petraglia, N. Boivin, \& R. Crassard (Eds.), Human dispersal and species movement: From prehistory to the present (pp. 304-331). Cambridge: Cambridge University Press.

Fuller, D. Q., MacDonald, K. C., \& Vernet, R. (2007). Early domesticated pearl millet in Dhar Nema (Mauritania): Evidence of crop processing waste as ceramic temper. In R. T. J. Cappers (Ed.), Fields of change: Progress in African archaeobotany (pp. 71-76). Groningen: Barkhuis / Groningen University Library.

Fuller, D. Q., Asouti, E., \& Purugganan, M. D. (2012). Cultivation as slow evolutionary entanglement: Comparative data on rate and sequence of domestication. Vegetation History and Archaeobotany, 21(2), 131-145. https://doi.org/10.1007 /s00334-011-0329-8.

Fuller, D. Q., Denham, T. P., Arroyo Kalin, M., Lucas, L., Stevens, C. J., Qin, L., Allaby, R. G., \& Purugganan, M. D. (2014). Convergent evolution and parallelism in plant domestication revealed by an expanding archaeological record. Proceedings of the National Academy of Sciences, 111(17), 6147-6152. https://doi.org/10.1073/pnas.1308937110.

Fuller, D. Q., Colledge, S., Murphy, C., \& Stevens, C. J. (2017). Sizing up cereal variation: Patterns in grain evolution revealed in chronological and geographical comparisons. In J. Fernández Eraso, J. A. Mujika Alustiza, A. Arrizabalaga Valbuena, \& M. García Diez (Eds.), Miscelánea en homenaje a Lydia Zapata Peña (1965-2015) (pp. 131-149). Bilbao: Universidad del País Vasco.

Fuller, D. Q., Lucas, L., Gonzalez Carretero, L., \& Stevens, C. J. (2018). From intermediate economies to agriculture: Trends in wild food use, domestication and cultivation among early villages in Southwest Asia. Paléorient, 44, 61-76. 
Gepts, P. (2014). The contribution of genetic and genomic approaches to plant domestication studies. Current Opinion in Plant Biology, 18, 51-59.

Godbole, S. V. (1928). Studies on the Bajra crop I: The morphology of Pennisetum typhoideum. Memoirs of the Department of Agriculture in India (Pusa), 14, 247-268.

Hammer, Ø., Harper, D. A. T., \& Ryan, P. D. (2001). Past: Paleontological statistics software package for education and data analysis. Palaeontologia electronica, 4(1), 1-9 http://palaeo-electronica.org.

Harlan, J. R. (1992). Indigenous African agriculture. In C. W. Cowan \& P. J. Watson (Eds.), The origins of agriculture (pp. 59-70). Washington: Smithsonian Institution.

Harlan, J. R., de Wet, J. M. J., \& Price, E. G. (1973). Comparative evolution of cereals. Evolution, 27(2), 311-325.

Kahlheber, S. (2004). Perlhirse und baobab: Archäobotanische untersuchungen im Norden Burkina Faso. Ph.D. Dissertation. Fankfurt: Johann Wolfgang GoetheUniversität.

Kahlheber, S., Höhn, A., \& Rupp, N. (2009). Archaeobotanical studies at Nok sites: An interim report. Nyame Akuma, 71, 217.

Klee, M., Zach, B., \& Neumann, K. (2000). Four thousand years of plant exploitation in the Chad Basin of northeast Nigeria I: The archaeobotany of Kursakata. Vegetation History and Archaeobotany, 9(4), 223-237.

Kunth, C. S. (1835). Distribution méthodique de la famille des Graminées. Paris: Gide.

Larson, G., Piperno, D. R., Allaby, R. G., Purugganan, M. D., Andersson, L., Arroyo-Kalin, M., Barton, L., Climer Vigueira, C., Denham, T., Dobney, K., Doust, A. N., Gepts, P., Gilbert, M. T. P., Gremillion, K. J., Lucas, L., Lukens, L., Marshall, F. B., Olsen, K. M., Pires, J. C., Richerson, P. J., Rubio de Casas, R., Sanjur, O. I., Thomas, M. G., \& Fuller, D. Q. (2014). Current perspectives and the future of domestication studies. Proceedings of the National Academy of Sciences, 111(17), 6139-6146.

Latham, S. J., Varslot, T. K., \& Sheppard, A. P. (2008). Automated registration for augmenting micro-CT $3 \mathrm{D}$ images. The ANZIAM Journal, 50, C534-C548.

Limaye, A. (2012). Drishti: A volume exploration and presentation tool. In S. R. Stock (Ed.), Developments in X-Ray Tomography VIII (p. 85060X1-9). Bellingham: SPIE, The International Society for Optics and Photonics. https://doi. org/10.1117/12.935640.

MacDonald, K. C., Vernet, R., Martinón Torres, M., \& Fuller, D. Q. (2009). Dhar Néma: From early agriculture to metallurgy in southeastern Mauritania. Azania: Archaeological Research in Africa, 44(1), 3-48.

MacDonald, K. C., Champion, L., \& Manning, K. (2017). Windé Koroji Ouest (Mali, Second and Third Millennia BCE): The environmental and subsistence evidence. In N. Rupp, C. Beck, G. Franke, \& K. P. Wendt (Eds.), Winds of change: Archaeological contributions in honour of Peter Breunig (pp. 165-180). Bonn: Rudolf Habelt.

Mann, H. B. (1945). Non-parametric tests against trend. Econometrica, 13, 163-171.

Manning, K., \& Fuller, D. Q. (2014). Early millet farmers in the Lower Tilemsi Valley, Northeastern Mali. In C. J. Stevens, S. Nixon, M. A. Murray, \& D. Q. Fuller (Eds.), The archaeology of African plant use (pp. 73-81). Walnut Creek: Left Coast.

Manning, K., \& Timpson, A. (2014). The demographic response to Holocene climate change in the Sahara. Quaternary Science Reviews, 101, 28-35.

Manning, K., Pelling, R., Higham, T. F. G., Schwenniger, J.-L., \& Fuller, D. Q. (2011). 4500-Year old domesticated pearl millet (Pennisetum glaucum) from the Tilemsi Valley, Mali: New insights into an alternative cereal domestication pathway. Journal of Archaeological Science, 38(2), 312-322. https://doi.org/10.1016/j.jas.2010.09.007.

Marchais, L. (1994). Wild pearl millet population (Pennisetum glaucum, Poaceae) integrity in agricultural Sahelian areas. An example from Keita (Niger). Plant systematics and evolution, 189, 233-245. https://doi.org/10.1007/BF00939729.

McClatchie, M., \& Fuller, D. Q. (2014). Leaving a lasting impression: Arable economies and cereal impressions in Africa and Europe. In C. J. Stevens, S. Nixon, M. A. Murray, \& D. Q. Fuller (Eds.), The archaeology of African plant use (pp. 256266). Walnut Creek: Left Coast.

Mercuri, A. M. (2001). Preliminary analyses of fruits, seeds and few plant macrofossils from the Early Holocene sequence. In E. A. A. Garcea (Ed.), Uan Tabu in the settlement history of the Libyan Sahara (pp. 189-210). Firenze: All'Insegna del Giglio (Arid Zone Archaeology Monographs 2).

Mercuri, A. M., Fornaciari, R., Gallinaro, M., Vanin, S., \& Di Lernia, S. (2018). Plant behaviour from human imprints and the cultivation of wild cereals in Holocene Sahara. Nature Plants, 4(2), 71-81.

Meyer, R. S., \& Purugganan, M. D. (2013). Evolution of crop species: Genetics of domestication and diversification. Nature Reviews Genetics, 14(12), 840-852.

Murray, S. S., \& Déme, A. (2014). Agro-pastoralism in the Middle Senegal valley: The botanical remains from Walaldé. In C. J. Stevens, S. Nixon, M. A. Murray, \& D. Q. Fuller (Eds.), The archaeology of African plant use (pp. 97-102). Walnut Creek: Left Coast.

Murray, M. A., Fuller, D. Q. \& Cappeza, C. (2007) Crop production on the Senegal River in the early First Millennium AD: preliminary aechaeobotanical results from Cubalel. In R. T. J. Cappers (Ed.) Fields of Change. Progress in African Archaeobotany. Grongingen Archaeological Studies 5. (pp. 63-70). Groningen: Barkhuis Publishing.

Myers, G. R., Kingston, A. M., Varslot, T. K., \& Sheppard, A. P. (2011). Extending reference scan drift correction to highmagnification high-cone-angle tomography. Optics Letters, 36(24), 4809-4811.

Neumann, K., Ballouche, A., \& Klee, M. (1996). The emergence of plant food production in the West African Sahel: new evidence from northeast Nigeria and northern Burkina Faso. In G. Pwiti \& R. Soper (Eds.), Aspects of African archaeology. Papers from the 10th Congress of the Panafrican Association for Prehistory and related Studies (pp. 441-448). Harare: University of Zimbabwe.

Oas, S. E., D'Andrea, A. C., \& Watson, D. J. (2015). 10,000 year history of plant use at Bosumpra Cave, Ghana. Vegetation History and Archaeobotany, 24(5), 635-653.

Olson, D. M., Dinerstein, E., Wikramanayake, E. D., Burgess, N. D., Powell, G. V. N., Underwood, E. C., D'Amico, J. A., Itoua, I., Strand, H. E., Morrison, J. C., Loucks, C. J., Allnutt, T. F., Ricketts, T. H., Kura, Y., Lamoreux, J. F., Wettengel, 
W. W., Hedao, P., \& Kassem, K. R. (2001). Terrestrial ecoregions of the world: A new map of life on earth: A new global map of terrestrial ecoregions provides an innovative tool for conserving biodiversity. BioScience, 51(11), 933-938. https://doi.org/10.1641/0006-3568(2001)051 [0933:TEOTWA]2.0.CO;2.

Ozainne, S., Lespez, L., Le Drezen, Y., Eichhorn, B., Neumann, K., \& Huysecom, E. (2009). Developing a chronology integrating archaeological and environmental data from different contexts: The Late Holocene sequence of Ounjougou (Mali). In I. Hajdas, P. D. Casa, M. Egli, U. Hügi, S. Van Willigen, \& M. Wörle (Eds.), Proceedings of the 5th radiocarbon \& archaeology international symposium (pp. 457-470). Yale: University (Radiocarbon 51/2).

Pearson, E. S., \& Hartley, H. O. (1976). Biometrika tables for statisticians. Cambridge, UK: Biometrika Trust.

Pelling, R. (2007). Agriculture and trade amongst the Garamantes: 3000 years of archaeobotanical data from the Sahara and its margins. Ph.D. Dissertation. University College London.

Petit-Maire, N. (Ed.). (1991). Paléoenvironnements du Sahara: Lacs holocènes à Taoudenni (Mali). Paris: Editions du CNRS.

Petit-Maire, N., \& Riser, J. (Eds.). (1983). Sahara ou Sahel? Quaternaire récent du Bassin de Taoudenni (Mali). Marseille: Imprimerie Lamy.

Piperno, D. R. (2017). Assessing elements of an extended evolutionary synthesis for plant domestication and agricultural origin research. Proceedings of the National Academy of Sciences, 114(25), 6429-6437.

Pokharia, A. K., Kharakwal, J. S., \& Srivastava, A. (2014). Archaeobotanical evidence of millets in the Indian subcontinent with some observations on their role in the Indus civilization. Journal of Archaeological Science, 42, 442-455. https://doi.org/10.1016/j.jas.2013.11.029.

Poncet, V., Lamy, F., Devos, K. M., Gale, M. D., Sarr, A., \& Robert, T. (2000). Genetic control of domestication traits in pearl millet (Pennisetum glaucum L., Poaceae). Theoretical and Applied Genetics, 100(1), 147-159. https://doi. org/10.1007/s001220050020.

Purugganan, M. D., \& Fuller, D. Q. (2011). Archaeological data reveal slow rates of evolution during plant domestication. Evolution, 65(1), 171-183.

Raimbault, M. (1994). Sahara malien. Environnement, populations et industries préhistoriques. Thèse Doctorat Etat : Préhistoire. Université Aix-Marseille I.

Reale Accademia di Scienze, Lettere ed Arti. (1786). Saggi Scientifici e Litterari dell'Accademia di Padova (Vol. 1). Padova.

Serba, D. D., Yadav, R. S., Varshney, R. K., Gupta, S. K., Mahalingam, G., Srivastava, R. K., Gupta, R., Perumal, R., \& Tesso, T. T. (2020). Genomic esigning of Pearl Millet: A resilient crop for arid and semi-arid environments. In C. Kole (Ed.), Genomic designing of climate-smart cereal crops (pp. 221-286). Cham: Springer.
Steele, W. M., \& Bunting, A. H. (1982). Plant remains from the mortar 192.2.10 from Qasr Ibrim. In A. J. Mills (Ed.), The cemeteries of Qasr Ibrim (pp. 86-87). London: Egypt Exploration Society.

Stevens, C. J., \& Fuller, D. Q. (2018). Sorghum and pearl millet. In S. L. López Varela (Ed.), The encyclopedia of Archaeological sciences (pp. 1-4). Hoboken: Wiley. https://doi.org/10.1002/9781119188230.saseas0542.

Tostain, S. (1998). Le mil, une longue histoire: Hypothèses sur sa domestication et ses migrations. In M. Chastanet (Ed.), Plantes et paysages d'Afrique: Une histoire à explorer (pp. 461-490). Paris: Karthala / Centre de recherches africaines.

Upadhyaya, H. D., Reddy, K. N., Ahmed, M. I., Kumar, V., Gumma, M. K., \& Ramachandran, S. (2017). Geographical distribution of traits and diversity in the world collection of pearl millet [Pennisetum glaucum (L.) R. Br., synonym: Cenchrus americanus (L.) Morrone] landraces conserved at the ICRISAT genebank. Genetic Resources and Crop Evolution, 64(6), 1365-1381.

Wasylikowa, K. (1993). Plant macrofossils from the archaeological sites of Uan Muhuggiag and Ti-n-Torha, southwestern Libya. In L. Krzyzaniak, M. Kobusiewicz, \& J. A. Alexander (Eds.), Environmental change and human culture in the Nile Basin and northern Africa until the second millennium BC (pp. 25-42). Poznan: Archaeological Museum (Studies in African Archaeology).

Winchell, F., Stevens, C. J., Murphy, C., Champion, L., \& Fuller, D. Q. (2017). Evidence for sorghum domestication in fourth millennium BC eastern Sudan: Spikelet morphology from ceramic impressions of the Butana Group. Current Anthropology, 58(5), 673-683.

Winchell, F., Brass, M., Manzo, A., Beldados, A., Perna, V., Murphy, C., Stevens, C. J., \& Fuller, D. Q. (2018). On the origins and dissemination of domesticated sorghum and pearl millet across Africa and into India: A view from the Butana Group of the Far Eastern Sahel. African Archaeological Review, 35(4), 483-505. https://doi.org/10.1007/s10437018-9314-2.

Wotzka, H.-P. (2019). Ecology and culture of millets in African rainforests: Ancient, historical, and present-day evidence. In B. Eichhorn \& A. Höhn (Eds.), Trees, grasses and crops: People and plants in sub-Saharan Africa and beyond (pp. 407-429). Bonn: Rudolf Habelt.

Zach, B., \& Klee, M. (2003). Four thousand years of plant exploitation in the Chad Basin of NE Nigeria II: Discussion on the morphology of caryopses of domesticated Pennisetum and complete catalogue of the fruits and seeds of Kursakata. Vegetation History and Archaeobotany, 12(3), 187-204.

Publisher's Note Springer Nature remains neutral with regard to jurisdictional claims in published maps and institutional affiliations. 